\title{
ANÁLISE DAS CONDIÇÕES DE MORADIA E DO MEIO AMBIENTE EM ASSENTAMENTOS PRECÁRIOS DA REGIÃO METROPOLITANA DE CURITIBA A PARTIR DO PAC HABITAÇÃO ${ }^{1}$
}

\section{Analysis of housing and environmental conditions in precarious settlements of the Metropolitan Region of Curitiba from the PAC Housing}

Fabiana Alves Monteiro Doutoranda em Geografia, do Programa de Pós-Graduação em Geografia da Universidade Federal do Paraná fabianamote15@gmail.com

Artigo enviado para publicação em 12/04/2019 e aceito em 14/08/2019

DOI: $10.12957 /$ tamoios.2019.38265

\section{Resumo}

O presente trabalho tem por objetivo analisar que transformações socioambientais ocorreram em assentamentos de três municípios integrantes da Região Metropolitana de Curitiba (RMC): Campo Magro, Colombo e Piraquara, a partir da intervenção do poder público. Os assentamentos aqui analisados foram selecionados no ano de 2007 através do Programa de Aceleração do Crescimento (PAC) no eixo Habitação, para passar por um processo de urbanização e recuperação ambiental a ser implementado pela Companhia de Habitação do Paraná (COHAPAR) em parceria com as Prefeituras Municipais. Para realização desse trabalho, buscou-se analisar primeiramente a problemática da moradia e os resultados alcançados até o presente momento pelo PAC Habitação na RMC, tendo como base uma pesquisa bibliográfica com estudiosos do assunto, informações disponibilizadas por órgãos oficiais como o Ministério das Cidades e pesquisa de campo na área selecionada.

Palavras-chave: Assentamentos precários; meio ambiente; poder público; moradia; intervenção.

\begin{abstract}
The objective of this study is to analyze the socioenvironmental transformations that took place in three municipalities belonging to the Metropolitan Region of Curitiba (RMC): Campo Magro, Colombo and Piraquara, as a result of public intervention. The settlements analyzed here were selected in 2007 through the Growth Acceleration Program (PAC) in the Housing axis, to undergo a process of urbanization and environmental recovery to be implemented by the Housing Company of Paraná (COHAPAR) in partnership with the City Halls. In order to carry out this work, we sought to first analyze the housing problem and the results achieved so far by the PAC Housing in the RMC, based on a bibliographical research with scholars, information made available by official bodies such as the Ministry of Cities and the selected area.
\end{abstract}

Keywords: Precarious settlements; environment; public power; dwellings; intervention. 


\section{Introdução}

Conforme a literatura crítica aponta, as políticas urbanas são instrumentos que o Estado utiliza para atender, ainda que indiretamente, aos interesses do capital (Miliband, 1972; Lojkine, 1977). Além disso, para esta corrente, o Estado tem caráter de classe e segundo Marques (1997), embora existam diferentes formas de abordar a relação entre Estado e capital, a subordinação do primeiro ao segundo é intrínseca, ainda que de forma indireta.

Levando em consideração esta argumentação, observa-se que no Brasil, historicamente, o Estado tem atuado mais como facilitador do que como responsável direto pela produção habitacional, que tem ficado a cargo da iniciativa privada. Além disso, as políticas habitacionais desenvolvidas no âmbito federal são esparsas, padronizadas e descontínuas, configurando muito mais Políticas de Governo do que Políticas de Estado, estando, portanto, sujeitas às oscilações no cenário político e econômico do país.

Contudo, Rufino (2012) afirma que tais políticas geralmente fortalecem simbolicamente o Estado, na medida em que atendem parcialmente as reinvindicações da população, dos movimentos sociais organizados e setores políticos. Além de que, Políticas Públicas e Programas Federais de grande visibilidade, a exemplo do Minha Casa Minha Vida (MCMV), ao promoverem a produção de habitação em massa e fomentarem a ideologia da casa própria nas classes de baixa e média renda acabam por aquecer determinados setores econômicos, atendendo assim, também seus interesses. Dessa forma, a autora ressalta que o recente estreitamento das relações entre o mercado imobiliário e o Estado, através desse Programa tem beneficiado a ambos. Pois o Estado, ao fortalecer este mercado, também se beneficia, ao apropriar-se integralmente dos resultados do Programa, incorporando os números da produção habitacional realizada pela iniciativa privada como se fosse "parte de uma política pública". Dessa forma, essa aliança tem se mostrado vantajosa para o mercado imobiliário porque tem vivenciado um crescimento nos últimos anos e para o Estado porque tem garantido a "capitalização política" com a grande produção do Programa MCMV (RUFINO, 2012, p.285).

Todavia, ainda que permeada dos interesses das classes de alta renda, as políticas públicas e especialmente as políticas habitacionais, são fundamentais para facilitar o acesso à moradia às camadas de baixa renda do país. Pois, fatores como o preço da terra, a especulação imobiliária e a desigualdade social, muitas vezes fomentados pelo próprio Estado, são responsáveis por dificultar ou mesmo impossibilitar o acesso dessa população ao mercado imobiliário formal.

Entretanto, após o esfacelamento da Política Habitacional implementada durante o Regime Militar (1964-1986), o país vivenciou na década de 1990 um período em que o Governo Federal abriu mão de políticas centralizadoras a fim de atribuir maior autonomia e responsabilidade aos municípios, resultando numa queda na produção de habitações destinadas a população de menor renda. Pois, mesmo com os resultados positivos de alguns Programas dessa época, como o Pró-Moradia e o Habitar Brasil, o alcance foi limitado e ficou restrito a alguns poucos municípios que dispunham de recursos suficientes para investir e equipe técnica especializada.

Sobre a relevância da habitação popular durante o Regime militar, Bonduki (2008), afirma que foi somente nesse período que o Brasil desenvolveu de fato, uma Política de abrangência nacional, com a criação do Sistema Financeiro da Habitação $(\mathrm{SFH})^{2}$ em 1964 e que segundo o autor, 
(...) financiou a construção de 4,3 milhões de unidades novas, das quais 2,4 com recursos do FGTS, para o setor popular, e 1,9 milhões com recursos do SBPE, para o mercado de habitação para a classe média. Se for considerado o período até 2000, pois o SFH continuou funcionando após a extinção do BNH em 1986, foram financiadas cerca de 6,5 milhões de unidades habitacionais (BONDUKI, 2008, p. 73).

O órgão central do Sistema, segundo o autor, era o Banco Nacional da Habitação (BNH), responsável pelo gerenciamento do FGTS, pela normatização e fiscalização da aplicação dos recursos das cadernetas de poupança e pela definição das condições de financiamento das moradias. Porém, Bonduki (2008), reitera que na produção habitacional, esse Sistema deixou muito a desejar frente às necessidades que se intensificaram nessa época. Destacando que entre 1950 a 2000 a população urbana de cidades com mais de 20 mil habitantes passou de 11 milhões para 125 milhões, e que no período de vigência do BNH (1964-1986), "foram financiadas cerca de $25 \%$ das novas moradias construídas no país, porcentagem relevante, mas totalmente insuficiente para enfrentar o desafio da urbanização brasileira" (BONDUKI, 2008, p. 73).

Além do seu alcance limitado, muitos autores criticam também o padrão e a localização desses empreendimentos implantados durante o Regime Militar e voltados às famílias de baixa renda, como Milton Santos (1996),

\begin{abstract}
Os conjuntos residenciais levantados com dinheiro público - mas por firmas privadas - para as classes médias baixas e os pobres se situam quase invariavelmente nas periferias urbanas, a pretexto dos preços mais acessíveis dos terrenos, levando, quando havia pressões, a extensões de serviços públicos como luz, água, às vezes esgotos, pavimentação e transportes, custeados, também, com os mesmos recursos. É desse modo que o BNH contribui para agravar a tendência ao espraiamento das cidades e para estimular a especulação imobiliária. A construção de um conjunto residencial e a consecutiva dotação de infraestruturas valoriza os terrenos ao derredor, estimulando os proprietários a uma espera especulativa. Produzem-se novos vazios urbanos, ao passo que a população necessitada de habitação, mas sem poder pagar pelo seu preço nas áreas mais equipadas, deve deslocar-se para mais longe, ampliando o processo de periferização (SANTOS, 1996, p. 112).
\end{abstract}

Na Região Metropolitana de Curitiba (RMC), está época marca, segundo Lima (2000), um crescimento no número de assentamentos informais em áreas inadequadas à moradia, principalmente em áreas de mananciais na porção norte e leste de Curitiba. Esse aumento da informalidade da moradia é parte do processo de metropolização de Curitiba, que de acordo com Firkowski (2001), tem suas origens na década de 1970 e se consolidou nos anos de 1990, tendo como uma das suas principais características a exclusão de parte da população pobre para os municípios periféricos da metrópole.

A partir dos anos 2000, com um novo cenário político e econômico se consolidando no Brasil, tem início a formulação e implementação de uma Nova Política Habitacional. É aprovado então, o Estatuto da Cidade em 2001, que de acordo com Ferreira (2012), foi de fundamental importância, pois regulamentou "importantes instrumentos para que os poderes públicos municipais enfrentassem o mau uso da terra urbana, a retenção especulativa, a informalidade da posse, ou ainda facilitassem o seu acesso pelas camadas de mais baixa renda" (FERREIRA, 2012, p. 53).

Em 2003 é criado o Ministério das Cidades ${ }^{3}$ e em 2004, uma nova Política Habitacional, sendo que o seu princípio fundamental era justamente possibilitar o acesso à moradia às classes de menor renda. Também foram criados alguns instrumentos como o Sistema Nacional de Habitação de Interesse Social (SNHIS) e o Fundo Nacional de 
Habitação de Interesse Social (FNHIS) em 2005 e o Programa de Aceleração do Crescimento (PAC) em 2007, cujo eixo Habitação foi responsável por aumentar consideravelmente o volume de recursos destinados à empreendimentos de urbanização, principalmente através do Programa de Urbanização de Assentamentos Precários (UAP).

Este Programa em sua primeira fase (2007-2009) teve como objetivo selecionar Projetos voltados a urbanizar assentamentos de grande porte e complexidade ambiental em todo o Brasil, chamados então de Projetos Prioritários de Investimentos (PPI). É o caso dos Projetos aqui analisados: Urbanização Passaúna em Campo Magro, Roça Grande em Colombo e Guarituba em Piraquara. Na segunda fase do Programa (2011-2014), as seleções de Projetos passaram a ser anuais e foram direcionadas ao atendimento de assentamentos de menor porte. Ainda como parte da Política Habitacional desse período, foi criado em 2009 o já mencionado Programa MCMV e o MCMV Entidades. Este último, destinado a financiar a construção de moradias por cooperativas ou associações habilitadas pela Caixa Econômica Federal.

Apesar do PAC Habitação ter possibilitado um maior volume de recursos destinados a Habitação de Interesse Social, Cardoso, Aragão \& Araújo (2011) reiteram que ele causou um deslocamento na centralidade do FNHIS na Política Habitacional, passando a submeter todos os programas governamentais com o impacto no crescimento econômico. E, ao contrário deste, os recursos do PAC não são submetidos a mecanismos de controle social ou a critérios institucionais de redistribuição, "sendo a sua alocação prerrogativa exclusiva da Casa Civil da Presidência da República”. Além disso, o Programa representou um afastamento das politicas públicas que vinham então sendo construídas com a participação popular nas últimas décadas (CARDOSO, ARAGÃO \& JAENISCH, 2017, p. 4).

Ademais, os autores colocam que um dos impactos mais imediatos sobre os Programas que foram desenvolvidos no âmbito do FNHIS, diz respeito à eliminação dos repasses de recursos para as ações de provisão habitacional. Dessa forma, desde o lançamento do Programa MCMV, o Fundo passou a concentrar os seus recursos nas ações de urbanização de assentamentos precários e de desenvolvimento institucional, seguindo orientação do então Ministério das Cidades, acatada pelo Conselho Gestor. E, com a consolidação do MCMV, ele sofreu um esvaziamento de recursos na administração de Dilma Rousseff (2011-2016). Os autores afirmam também que desde o ano de 2014, com a ampliação da crise política e econômica do Brasil, o Setor da Habitação vem passando por um processo de retração, resultando numa diminuição do crédito e do volume de recursos destinados aos Programas Habitacionais.

Constatou-se ainda neste trabalho que muitos dos empreendimentos do Programa UAP na implementados na RMC estão paralisados ou em situação de atraso, principalmente no que se refere às etapas de regularização fundiária e recuperação ambiental, conforme se poderá verificar posteriormente.

Dessa forma, o presente trabalho se propõe a analisar que transformações socioambientais ocorreram nos assentamentos dos municípios de Campo Magro, Colombo e Piraquara, localizados no entorno de Curitiba, a partir da implementação do PAC Habitação, além de trazer um panorama geral dos resultados preliminares desse Programa na RMC. Para tanto, a pesquisa se fundamentou em uma revisão bibliográfica com estudiosos da temática e informações provenientes de órgãos como o Ministério das Cidades e da Companhia de Habitação do Paraná (COHAPAR), além daquelas fornecidas pelas Prefeituras Municipais e coletadas através de entrevistas semiabertas com as famílias relocadas para os conjuntos habitacionais previstos nestes Projetos de Intervenção. 


\section{$\overline{\text { A problemática da moradia e o PAC Habitação na Região Metropolitana de }}$ Curitiba}

Conforme mencionado anteriormente, com o processo de metropolização de Curitiba, iniciado na década de 1970 e consolidado na de 1990, houve um aumento da informalidade da moradia nas porções norte e leste da capital. Dentre estes municípios, destacam-se além da capital, Piraquara e Colombo, que conforme a Tabela 1, tiveram um crescimento expressivo de população residente em assentamentos precários entre os anos de 1992 e 1998. Ressaltando que, segundo a COMEC (2012), o município de Piraquara é responsável por cerca de 50\% do abastecimento de água da RMC e 92\% do seu território é constituído em Áreas de Proteção Ambiental (APAs).

Tabela 1 - Domicílios e população residente em assentamentos de Curitiba e municípios pesquisados entre 1992 e 1998

\begin{tabular}{l|c|c|cc}
\hline Município & $\begin{array}{c}\text { Domicílios } \\
\mathbf{1 9 9 2}\end{array}$ & $\begin{array}{c}\text { Domicílios } \\
\mathbf{1 9 9 8}\end{array}$ & $\begin{array}{c}\text { População residente } \\
\text { em assentamentos } \\
\mathbf{( 1 9 9 2 )}\end{array}$ & $\begin{array}{c}\text { População residente } \\
\text { em assentamentos } \\
\mathbf{( 1 9 9 8 )}\end{array}$ \\
\hline Curitiba & 44.713 & 53.162 & 165.438 & 196.699 \\
\hline Campo Magro & - & 1.723 & - & 6.375 \\
\hline Colombo & 3.303 & 6.253 & 13.740 & 23.136 \\
\hline Piraquara & 197 & 4.199 & 648 & 15.536 \\
\hline
\end{tabular}

Fonte: SILVA (2012).

Elaboração: A autora (2019).

Esse contínuo aumento no número de famílias residindo em áreas de mananciais de abastecimento público resultou em algumas medidas tomadas pelo poder público nesse período para garantir o abastecimento de água da RMC.

Essa época é marcada também por um avanço no debate acerca da questão ambiental que, de acordo com Acselrad (2010), encontra apoio na noção de "ambientalização", que pode designar tanto "o processo de adoção de um discurso ambiental genérico por parte dos diferentes grupos sociais, como a incorporação concreta de justificativas ambientais para legitimar práticas institucionais, políticas, científicas etc." (ACSELRAD, 2010, p.103).

Verifica-se dessa forma, que na RMC, o poder público local parece ter se ancorado na noção de "ambientalização" que incorpora justificativas ambientais, passando assim, a legitimar suas práticas institucionais e políticas. Pois, conforme afirma a COMEC (2006), a delimitação de áreas de mananciais de abastecimento está diretamente ligada a Lei Estadual $n^{\circ}$. 8.935/89, que dispõe sobre os recursos mínimos para as águas provenientes de bacias de mananciais destinadas ao abastecimento público, determinando que devem satisfazer a Classe 2, conforme Resolução do CONAMA ${ }^{5}, \mathrm{n}^{\circ}$. 20/86. E, que foi a partir dessa Lei que o Estado do Paraná passou a contar com um instrumento que estipulou de modo simplificado os usos considerados adequados a uma área de manancial e as obrigações geradas para sua proteção.

Entretanto, de acordo com a própria COMEC (2006), isso acabou estabelecendo critérios genéricos e levou ao poder público impedir a aprovação de loteamentos populares em áreas de manancial. Como consequência, Lima (2000), afirma que houve um aumento no número de ocupações irregulares nestas áreas, principalmente no vetor leste de expansão metropolitana, sobretudo na região do Guarituba no município de Piraquara, em loteamentos que haviam sido aprovados entre 1950 e 1960, mas que, em função da aprovação de legislações restritivas e falta de infraestrutura não haviam sido implantados. 
Dessa forma, a COMEC (2006) coloca que é apenas após a aprovação da Lei Estadual $\mathrm{n}^{\circ}$. 12.248/98 que vai ocorrer uma adequação das normas vigentes à realidade da RMC, onde foi estabelecido um processo de regulamentação do uso do solo nas áreas de mananciais, cujo foco principal era o ordenamento territorial comprometido com a sustentabilidade da metrópole. Sendo que essa Lei rompeu com o modelo que vigorava até então na RMC, onde essas áreas que sofriam forte pressão por ocupação deveriam ser altamente restritivas à habitação e se passou então a tratar de suas necessidades de forma individual. Além disso, segundo a instituição, esse debate estava relacionado à elaboração do Sistema Estadual de Gerenciamento de Recursos Hídricos (SEGRH/PR), instituído através da Lei n ${ }^{\circ}$ 12.726/99, que veio a definir a Política de Recursos Hídricos do Estado do Paraná.

A criação da Lei $\mathrm{n}^{\circ}$. 12.248, também chamada de "Lei dos Mananciais", ainda resultou, de acordo com a COMEC (2006), na criação do Sistema Integrado de Gestão e Proteção dos Mananciais da Região Metropolitana de Curitiba (SIGPROM/RMC) e na criação de zoneamentos para áreas definidas como Unidades Territoriais de Planejamento (UTPs).

Segundo a COMEC (2006), o conceito de UTP surgiu da necessidade de ordenar parcelas do território compostas por sub bacias contribuintes dos mananciais, que englobavam um ou mais municípios e que estavam sob forte pressão por ocupação. Sendo o instrumento normativo mais importante da Lei dos Mananciais, logo que a criação e o zoneamento de uma UTP tem como resultado a definição de parâmetros de uso e ocupação do solo a serem instituídas por Decreto Estadual e detalhado posteriormente por Lei Municipal.

Uma UTP é subdividida em: Áreas de Restrição à ocupação; Áreas de Ocupação Orientada; Áreas de Urbanização Consolidada e Áreas Rurais. Além disso, a Lei possibilita a criação de Áreas de Interesse Social de Ocupação para atender aos assentamentos subnormais em Áreas de Urbanização Consolidada. Dessa forma, foram criadas no ano de 1999 as seguintes UTP's: Campo Magro, Itaqui, Pinhais, Quatro Barras e a do Guarituba. Esta última através do Decreto Estadual n ${ }^{\circ} .809 / 99$, englobando então parte das bacias do Irai, Piraquara e Itaqui. Além da instituição nesse período das APAs do Irai, Piraquara e Rio Pequeno, cujo objetivo era conservar a diversidade dos ambientes, espécies e processos naturais (COMEC, 2006).

Contudo, Souza (2015), chama atenção para a necessidade de se analisar criticamente a apropriação e instrumentalização do discurso da "proteção ambiental" pelo Estado e sua relação com conflitos pelo uso do solo no entorno de APPs e de unidades de conservação em geral que possam "justificar" a remoção de favelas.

Em relação aos fatores e processos responsáveis pelo crescimento da informalidade da moradia na RMC, Silva (2012) menciona a associação de três lógicas: "a da necessidade, por parte da população que reside nestes assentamentos; a da acumulação e reprodução do capital, vinculada à atividade imobiliária e à existência de um Estado subsidiário dos interesses privados" (SILVA, 2012, p. 235).

Cardoso (2007) por sua vez, ao analisar estes fatores, afirma que existem restrições macroestruturais que tornam a favela a solução possível para a falta de moradias para a população pobre. Contudo, o autor coloca que ao menos, a concepção de como o poder público tem de enfrentar essa problemática tem mudado nas últimas décadas e existe um consenso acerca da necessidade de urbanização e da promoção de melhoramentos nestas áreas, em detrimento das ações de remoção que caracterizaram suas ações no passado.

Essas novas alternativas para urbanizar favelas, segundo o autor, começaram a surgir na década de 1980, principalmente no âmbito municipal, e se disseminaram na 
década seguinte entre os municípios mais populosos. Para subsidiar estas ações, foram utilizados recursos locais e provenientes do Banco Mundial e do Banco Interamericano de Desenvolvimento (BID), que propunham modelos de urbanização com ações de políticas sociais. Entre os programas criados nesse período destaca-se o Programa Habitar-Brasil e Favela Bairro, ambos financiados pelo BID e implementados pela Prefeitura do Rio de Janeiro a partir de 1993 (CARDOSO, 2007).

Bonduki (2008) destaca também que a partir da Constituição de 1988 e da descentralização das políticas habitacionais, surgiram programas cujas propostas eram inovadoras, através da adoção de tipologias diversificadas, estímulo à participação e a autogestão da população, parceria como a sociedade organizada e articulação com a política urbana. São exemplos os programas alternativos com a adoção do mutirão na construção das moradias, o apoio à autoconstrução e os programas de urbanização de assentamentos precários como o Pró-Moradia.

Na RMC, desde a criação das Companhias de Habitação do Paraná na década de 1960, diferentes programas foram implementados para atender as diferentes faixas de renda da população, contando, para tanto, com recursos provenientes das mais variadas fontes. Todavia, conforme exposto na Tabela 1, o número de famílias residentes em assentamentos precários continuou aumentando de forma considerável nas décadas seguintes.

Ademais, na RMC os poucos os programas voltados especificamente à intervenção em favelas foram implementados quase que exclusivamente no município polo, através da Companhia de Habitação de Curitiba (COHAB-CT). Esta instituição, contando com recursos do Sistema Federal de Habitação (SFH), promoveu pela primeira vez em 1967, a relocação de famílias de diversos assentamentos para o conjunto habitacional Nossa Senhora da Luz, na Cidade Industrial de Curitiba (SILVA, 2012).

Já a COHAPAR, responsável pelos demais municípios da RMC, só passou a atuar de forma mais significativa a partir de meados dos anos 2000, quando passou a receber maior contingente de recursos do Governo Federal, principalmente a partir da criação do SNHIS em 2005 e do PAC Habitação em 2007.

No que diz respeito à implementação do PAC Habitação, seus recursos estão sendo investidos em obras de urbanização do Paraná desde o ano de 2007, através das Companhias de Habitação do estado. Nesta ocasião, o então presidente da COHAPAR, Rafael Greca, apresentou ao Ministério das Cidades e a Caixa Econômica Federal, 54 projetos de urbanização em aglomerados urbanos no Paraná. Dentre estes, sete foram aprovados e incorporados ao Programa UAP, quatro destes localizados em municípios da RMC: Campo Magro, Colombo, Pinhais e Piraquara. Os outros municípios que receberam recursos foram Foz do Iguaçu, Londrina e Maringá.

No momento dessa pesquisa, estava em andamento na RMC, através do PAC Habitação, empreendimentos de Urbanização e Provisão Habitacional (Quadro 1), além de Assistência Técnica, Lotes Urbanizados e elaboração de PLHIS. Tais empreendimentos estavam sendo implementados na capital através da COHAB-CT e nos demais municípios através da parceria da COHAPAR com as Prefeituras Municipais. 


\begin{tabular}{|c|c|c|c|c|c|c|c|}
\hline Município & $\begin{array}{l}\text { Empreendi- } \\
\text { mentos* }\end{array}$ & Subtipo & $\begin{array}{c}\text { Local da } \\
\text { intervenção }\end{array}$ & Seleção & $\begin{array}{c}\text { R\$ } \\
\text { Milhares } \\
\text { (Total)** }\end{array}$ & $\begin{array}{l}\text { Modali- } \\
\text { dade }\end{array}$ & $\begin{array}{c}\text { Situação e } \\
\text { \% de } \\
\text { execução } \\
2017 \\
\end{array}$ \\
\hline \multicolumn{8}{|c|}{ PAC 1} \\
\hline $\begin{array}{l}\text { Almirante } \\
\text { Tamandaré }\end{array}$ & $\begin{array}{c}\text { Provisão } \\
\text { habitacional - } \\
\text { Parque Hípico dos } \\
\text { Lagos }\end{array}$ & $\begin{array}{c}\text { Provisão } \\
\text { habitacional }\end{array}$ & $\begin{array}{c}\text { Parque Hípico dos } \\
\text { Lagos }\end{array}$ & $\mathrm{abr} / 08$ & $2.186,35$ & HIS & Concluída \\
\hline $\begin{array}{l}\text { Almirante } \\
\text { Tamandaré }\end{array}$ & $\begin{array}{c}\text { Provisão } \\
\text { habitacional - Vila } \\
\text { União } \\
\end{array}$ & $\begin{array}{c}\text { Provisão } \\
\text { habitacional }\end{array}$ & Vila União & $\mathrm{abr} / 08$ & 811,38 & HIS & Concluída \\
\hline Araucária & $\begin{array}{l}\text { Urbanização - } \\
\text { Capela Velha }\end{array}$ & Urbanização & $\begin{array}{c}\text { Capela Velha/Jd. } \\
\text { Arvoredo/C. da } \\
\text { Barra } \\
\end{array}$ & $\mathrm{abr} / 08$ & $9.886,71$ & UAP & $\begin{array}{l}\text { Atrasada } \\
58 \%\end{array}$ \\
\hline Campo Largo & $\begin{array}{c}\text { Provisão } \\
\text { habitacional }\end{array}$ & $\begin{array}{c}\text { Provisão } \\
\text { habitacional }\end{array}$ & $\begin{array}{l}\text { Lot. São Lucas, Pq. } \\
\text { Cambuí e outros }\end{array}$ & $\mathrm{dez} / 07$ & $2.928,34$ & HIS & Concluída \\
\hline $\begin{array}{l}\text { Campo } \\
\text { Magro }\end{array}$ & $\begin{array}{c}\text { Urbanização - } \\
\text { Passaúna }\end{array}$ & Urbanização & $\begin{array}{c}\text { Jd. Boa Vista e Jd. } \\
\text { Cecília }\end{array}$ & $\mathrm{dez} / 07$ & $14.098,37$ & UAP/PPI & $\begin{array}{c}\text { Atrasada } \\
98 \%\end{array}$ \\
\hline Colombo & $\begin{array}{c}\text { Urbanização - Roça } \\
\text { Grande (Jd. } \\
\text { Contorno, } \\
\text { Marambaia e V. } \\
\text { Liberdade) } \\
\end{array}$ & Urbanização & $\begin{array}{c}\text { Margens dos Rios } \\
\text { Palmital, Iraí e } \\
\text { Atuba }\end{array}$ & ago/07 & $19.929,15$ & UAP/PPI & $\begin{array}{l}\text { Paralisada } \\
57 \%\end{array}$ \\
\hline Colombo & $\begin{array}{c}\text { Urbanização - Jd. } \\
\text { Guaraituba e áreas } \\
\text { circunvizinhas }\end{array}$ & Urbanização & Jardim Guaraituba & ago/07 & $28.817,65$ & UAP/PPI & Concluída \\
\hline $\begin{array}{c}\text { Fazenda Rio } \\
\text { Grande }\end{array}$ & $\begin{array}{l}\text { Urbanização - B. } \\
\text { Gralha Azul, Sta. } \\
\text { Terezinha e Iguaçu }\end{array}$ & Urbanização & $\begin{array}{l}\text { B. Gralha Azul, Sta. } \\
\text { Terezinha e Iguaçu }\end{array}$ & set/07 & $3.573,39$ & UAP & Concluída \\
\hline Pinhais & Urbanização - Iraí & Urbanização & Bacia do R. Iraí & $\mathrm{dez} / 07$ & $43.9908,18$ & UAP/PPI & $\begin{array}{l}\text { Atrasada } \\
95 \%\end{array}$ \\
\hline Piraquara & $\begin{array}{c}\text { Urbanização - } \\
\text { Parque Guarituba }\end{array}$ & Urbanização & $\begin{array}{c}\text { Planta Fazenda } \\
\text { Guarituba }\end{array}$ & $\mathrm{dez} / 09$ & $4.521,45$ & UAP & Concluída \\
\hline Piraquara & $\begin{array}{c}\text { Urbanização - B. } \\
\text { Guarituba }\end{array}$ & Urbanização & Guarituba & ago/07 & $108.643,14$ & UAP/PPI & $\begin{array}{c}\text { Atrasada } \\
60 \%\end{array}$ \\
\hline $\begin{array}{l}\text { São José dos } \\
\text { Pinhais }\end{array}$ & $\begin{array}{c}\text { Urbanização - M. } \\
\text { Pinheiro e M. } \\
\text { Netuno }\end{array}$ & Urbanização & Rio Ressaca & nov/09 & $9.166,28$ & UAP & Concluída \\
\hline $\begin{array}{l}\text { São José dos } \\
\text { Pinhais }\end{array}$ & $\begin{array}{c}\text { Urbanização - B. } \\
\text { Guatupé e Borda do } \\
\text { Campo }\end{array}$ & Urbanização & $\begin{array}{c}\text { B. Guatupé e Borda } \\
\text { do Campo }\end{array}$ & Jun/08 & $33.400,00$ & UAP & Concluída \\
\hline \multicolumn{8}{|c|}{ PAC 2} \\
\hline $\begin{array}{l}\text { Campo } \\
\text { Magro }\end{array}$ & $\begin{array}{c}\text { Urbanização - } \\
\text { Morro da Formiga } \\
\end{array}$ & Urbanização & Morro da Formiga & Out/11 & $202.300,00$ & UAP/PPI & $\begin{array}{c}\text { Paralisada } \\
30 \% \\
\end{array}$ \\
\hline $\begin{array}{l}\text { Campo } \\
\text { Magro }\end{array}$ & $\begin{array}{c}\text { Urbanização - APA } \\
\text { do Passaúna }\end{array}$ & Urbanização & APA do Passaúna & Nov/11 & $13.038,82$ & UAP/PPI & $\begin{array}{c}\text { Paralisada } \\
12 \%\end{array}$ \\
\hline $\begin{array}{l}\text { São José dos } \\
\text { Pinhais }\end{array}$ & $\begin{array}{c}\text { Urbanização - Jd. } \\
\text { Modelo }\end{array}$ & Urbanização & $\begin{array}{l}\text { Jd. Modelo, B. São } \\
\text { Marcos (Netuno) }\end{array}$ & Out/11 & $370.57,00$ & UAP/PPI & $\begin{array}{c}\text { Atrasada } \\
50 \%\end{array}$ \\
\hline
\end{tabular}

Quadro 1 - Empreendimentos do PAC Habitação na RMC.

Fonte: BRASIL/ Ministério das Cidades (2017b).

Elaboração: A autora (2018).

* Empreendimentos do PAC Habitação na RMC, exceto Curitiba e os PLHIS dos municípios.

** Os valores do PAC Habitação incluem as unidades habitacionais do MCMV vinculado aos empreendimentos de urbanização.

O Quadro 1 permite verificar a situação de atraso ou paralisação em alguns desses empreendimentos. Nota-se que quatro deles, selecionados na primeira fase do Programa (2007-2009), estava com as obras em atraso e um encontrava-se paralisado: a urbanização Roça Grande no município de Colombo, analisada aqui de forma mais detalhada no próximo item. Neste empreendimento, apenas $57 \%$ das obras haviam sido executadas em aproximadamente dez anos. Já na segunda fase do Programa (2011-2014), quando o número de assentamentos selecionados para passar por intervenção foi bem reduzido - três no total e todos durante o ano de 2011, a situação ou era de atraso ou de paralização das obras. 
Já na capital, onde havia um número maior de assentamentos passando por intervenção, entretanto, o andamento das obras encontrava-se em situação mais crítica, conforme se pode observar no Quadro 2 a seguir.

\begin{tabular}{|c|c|c|c|c|c|c|c|}
\hline Empreendimentos & Fonte & Subtipo & Local & Seleção & $\begin{array}{c}\mathbf{R} \$ \\
\text { Milhares } \\
\text { (total) } \\
\end{array}$ & $\begin{array}{l}\text { Modali- } \\
\text { dade }\end{array}$ & $\begin{array}{r}\text { Situação e \% } \\
\text { de execução }\end{array}$ \\
\hline \multicolumn{8}{|c|}{ PAC 1} \\
\hline $\begin{array}{c}\text { Urbanização - Bacias } \\
\text { dos } \\
\text { R. Barigui, Iguaçu, } \\
\text { Belém e Atuba - V. } \\
\text { Unidos do Umbará }\end{array}$ & $\begin{array}{l}\text { FAT/ } \\
\text { FGTS }\end{array}$ & Urbanização & $\begin{array}{c}\text { Bacias dos R. Barigui, } \\
\text { Iguaçu, Belém e Atuba } \\
\text { - Vila Unidos do } \\
\text { Umbara }\end{array}$ & $\mathrm{Jul} / 08$ & $6.683,00$ & $\begin{array}{l}\text { Pro } \\
\text { Moradia }\end{array}$ & $\begin{array}{c}\text { Paralisada } \\
39 \%\end{array}$ \\
\hline $\begin{array}{c}\text { Urbanização - Bacias } \\
\text { dos R. Barigui, Iguaçu, } \\
\text { Belém e Atuba - Est. de } \\
\text { Santa Cândida }\end{array}$ & $\begin{array}{l}\text { FAT/ } \\
\text { FGTS }\end{array}$ & Urbanização & $\begin{array}{c}\text { Bacias dos R. Barigui, } \\
\text { Iguaçu, Belém e Atuba } \\
\text { - Estrada de Santa } \\
\text { Cândida } \\
\end{array}$ & dez/07 & $12.789,00$ & $\begin{array}{c}\text { Pro } \\
\text { Moradia }\end{array}$ & $\begin{array}{c}\text { Paralisada } \\
68 \%\end{array}$ \\
\hline $\begin{array}{c}\text { Urbanização - Bacias } \\
\text { dos } \\
\text { R. Barigui, Iguaçu, } \\
\text { Belém e Atuba } \\
\end{array}$ & $\begin{array}{l}\text { FAT/ } \\
\text { FGTS }\end{array}$ & Urbanização & $\begin{array}{c}\text { Bacias dos R. Barigui, } \\
\text { Iguaçu, Belém e Atuba } \\
\text { - R. Águas do } \\
\text { Passaúna } \\
\end{array}$ & dez/07 & $25.372,30$ & $\begin{array}{c}\text { Pro } \\
\text { Moradia }\end{array}$ & $\begin{array}{l}\text { Paralisada } \\
90 \%\end{array}$ \\
\hline $\begin{array}{c}\text { Urbanização - Bacias } \\
\text { dos } \\
\text { R. Barigui, Iguaçu, } \\
\text { Belém e Atuba - V. } \\
\text { Menino Jesus }\end{array}$ & $\begin{array}{l}\text { FAT/ } \\
\text { FGTS }\end{array}$ & Urbanização & Bairro Cajuru & jul/07 & $3.707,48$ & $\begin{array}{c}\text { Pro } \\
\text { Moradia }\end{array}$ & $\begin{array}{c}\text { Paralisada } \\
92 \%\end{array}$ \\
\hline $\begin{array}{c}\text { Urbanização - Bacias } \\
\text { dos } \\
\text { R. Barigui, Iguaçu, } \\
\text { Belém e Atuba - Vila } \\
\text { Pantanal } \\
\end{array}$ & $\begin{array}{l}\text { FAT/ } \\
\text { FGTS }\end{array}$ & Urbanização & $\begin{array}{c}\text { Bacias dos } \\
\text { R. Barigui, Iguaçu, } \\
\text { Belém e Atuba/ V. } \\
\text { Pantanal }\end{array}$ & jul/07 & $5.841,00$ & $\begin{array}{c}\text { Pro } \\
\text { Moradia }\end{array}$ & $\begin{array}{c}\text { Paralisada } \\
32 \%\end{array}$ \\
\hline $\begin{array}{c}\text { Urbanização - Bacias } \\
\text { dos } \\
\text { R. Barigui, Iguaçu, } \\
\text { Belém e Atuba - Vila } \\
\text { Nori e Três Pinheiros }\end{array}$ & $\begin{array}{l}\text { FAT/ } \\
\text { FGTS }\end{array}$ & Urbanização & $\begin{array}{c}\text { Bacias dos } \\
\text { R. Barigui, Iguaçu, } \\
\text { Belém e Atuba - Vila } \\
\text { Nori e Três Pinheiros } \\
\text { (Pilarzinho) }\end{array}$ & jul/07 & $10.240,84$ & $\begin{array}{c}\text { Pro } \\
\text { Moradia }\end{array}$ & $\begin{array}{c}\text { Atrasada } \\
55 \%\end{array}$ \\
\hline $\begin{array}{c}\text { Urbanização - Bacias } \\
\text { dos } \\
\text { R. Barigui, Iguaçu, } \\
\text { Belém e Atuba - Vila } \\
\text { Torres II }\end{array}$ & $\begin{array}{l}\text { FAT/ } \\
\text { FGTS }\end{array}$ & $\begin{array}{l}\text { Provisão } \\
\text { Habitacional }\end{array}$ & $\begin{array}{l}\text { Bacias dos R Barigui, } \\
\text { Iguacu, Belém e Atuba } \\
\text { - Vila Torres II }\end{array}$ & dez/07 & $7.409,64$ & $\begin{array}{c}\text { Pro } \\
\text { Moradia }\end{array}$ & $\begin{array}{l}\text { Atrasada } \\
50 \%\end{array}$ \\
\hline $\begin{array}{l}\text { Provisão Habitacional - } \\
\text { Bacias dos R. Barigui, } \\
\text { Iguaçu, Belém e Atuba }\end{array}$ & $\begin{array}{l}\text { FAT/ } \\
\text { FGTS }\end{array}$ & $\begin{array}{c}\text { Provisão } \\
\text { habitacional }\end{array}$ & $\begin{array}{l}\text { Bacias dos R. Barigui, } \\
\text { Iguaçu, Belém e Atuba } \\
\text { - Es. Del. Bruno de } \\
\text { Almeida }\end{array}$ & dez/07 & $8.764,00$ & $\begin{array}{c}\text { Pro } \\
\text { Moradia }\end{array}$ & Concluída \\
\hline $\begin{array}{c}\text { Urbanização - V. } \\
\text { Autódromo, Trindade }\end{array}$ & OGU & Urbanização & $\begin{array}{c}\text { V. Autódromo/ } \\
\text { Trindade, Rua Alberto } \\
\text { Gesser }\end{array}$ & $\mathrm{abr} / 08$ & $6.755,68$ & UAP & $\begin{array}{c}\text { Paralisada } \\
94 \%\end{array}$ \\
\hline $\begin{array}{c}\text { Urbanização - Terra } \\
\text { Santa } \\
\end{array}$ & OGU & Urbanização & $\begin{array}{c}\text { Tatuquara } \\
\text { Terra Santa } \\
\end{array}$ & dez/07 & $22.348,31$ & UAP/PPI & Concluída \\
\hline $\begin{array}{l}\text { Urbanização - V. Bela } \\
\text { Vista da Ordem e Beira } \\
\text { Rio } \\
\end{array}$ & OGU & Urbanização & Bairro Tatuquara & dez/09 & $8.561,22$ & UAP & $\begin{array}{c}\text { Paralisada } \\
16 \%\end{array}$ \\
\hline $\begin{array}{c}\text { Urbanização - V. } \\
\text { Parolin } \\
\end{array}$ & OGU & Urbanização & $\begin{array}{l}\text { Rua Brigadeiro } \\
\text { Franco, Parolin }\end{array}$ & dez/09 & $7.039,30$ & UAP & $\begin{array}{c}\text { Paralisada } \\
40 \%\end{array}$ \\
\hline \multicolumn{8}{|c|}{ PAC 2} \\
\hline $\begin{array}{c}\text { Urbanização - margens } \\
\text { do Arroio Xisto e } \\
\text { Padilha } \\
\end{array}$ & OGU & Urbanização & $\begin{array}{l}\text { Margens do Arroio } \\
\text { Xisto e Padilha/ CIC }\end{array}$ & Out/11 & $4.014,42$ & UAP/PPI & $\begin{array}{c}\text { Paralisada } \\
9 \%\end{array}$ \\
\hline Urbanização - V. Torres & OGU & Urbanização & Bairro Prado Velho & Nov/11 & $12.016,22$ & UAP/PPI & $\begin{array}{c}\text { Paralisada } \\
3 \% \\
\end{array}$ \\
\hline $\begin{array}{c}\text { Urbanização - V. Nova } \\
\text { Aurora, Americana e } \\
\text { Coqueiros } \\
\end{array}$ & OGU & Urbanização & $\begin{array}{c}\text { V. Nova } \\
\text { Aurora, Americana e } \\
\text { Coqueiros }\end{array}$ & Out/11 & $4.789,59$ & UAP/PPI & $\begin{array}{l}\text { Paralisada } \\
2 \%\end{array}$ \\
\hline $\begin{array}{l}\text { Urbanização - Moradias } \\
\text { Monteiro Lobato }\end{array}$ & OGU & Urbanização & $\begin{array}{c}\text { Moradias } \\
\text { Monteiro Lobato e } \\
\text { outros } \\
\end{array}$ & Out/11 & $6.549,18$ & UAP/PPI & $\begin{array}{c}\text { Paralisada } \\
20 \%\end{array}$ \\
\hline
\end{tabular}

Quadro 2 - Empreendimentos do PAC Habitação em Curitiba.

Fonte: BRASIL/Ministério das Cidades (2017b).

Elaboração: A autora (2018). 
Verifica-se que em Curitiba a maioria dos Projetos selecionados na primeira fase do PAC Habitação foram contratados na modalidade Pró Moradia. Este Programa foi criado em 1994 e reformulado pelo Ministério das Cidades em 2004, e é voltado a famílias com renda mensal de até 3 salários mínimos, utilizando como fonte de recursos o FGTS. Já na segunda fase os empreendimentos de urbanização foram contratados na modalidade UAP-PPI, que utiliza recursos do Orçamento Geral da União e também é voltada a famílias de baixa renda.

Dos empreendimentos contratados nessa primeira fase do Programa, apenas dois haviam sido concluídos até o momento da elaboração desta pesquisa, oito estavam paralisados, sem previsão de retorno das obras e dois estavam em situação de atraso, com cerca de 50\% das obras executadas. Já os empreendimentos da segunda fase estavam numa situação ainda mais crítica, pois as obras encontravam-se paralisadas com até $20 \%$ de execução e sem previsão de retorno.

Com as alterações na segunda fase do PAC Habitação, o Programa UAP passou a ser o responsável apenas pela urbanização de assentamentos onde é permitida a permanência dos moradores, enquanto o Programa MCMV foi incumbido de construir unidades habitacionais para o reassentamento destas famílias em locais apropriados.

Em Curitiba, esta segunda fase do Programa previa um investimento de $\mathrm{R} \$ 26,3$ milhões, com contrapartida de R\$ 1,3 milhão do município. Para a construção de 660 unidades habitacionais para as famílias com previsão de reassentamento foram repassados R\$ 29,7 milhões do Programa MCMV. Dessa forma, o total de recursos do PAC Habitação 2 na capital é de R \$ 57,3 milhões e a estimativa era que cerca de 2,6 mil famílias fossem beneficiadas através do Programa (COHAB-CT, 2017).

As Figuras 1 e 2 a seguir demonstram a distribuição espacial desses empreendimentos na RMC, na primeira e segunda fase e especificamente na capital, em relação aos assentamentos precários existentes. 
Figura 1 - Localização dos empreendimentos do PAC Habitação na RMC

\section{ASSENTAMENTOS PRECÁRIOS E EMPREENDIMENTOS DO PAC I E II NA REGIÃO METROPOLITANA DE CURITIBA/PR}

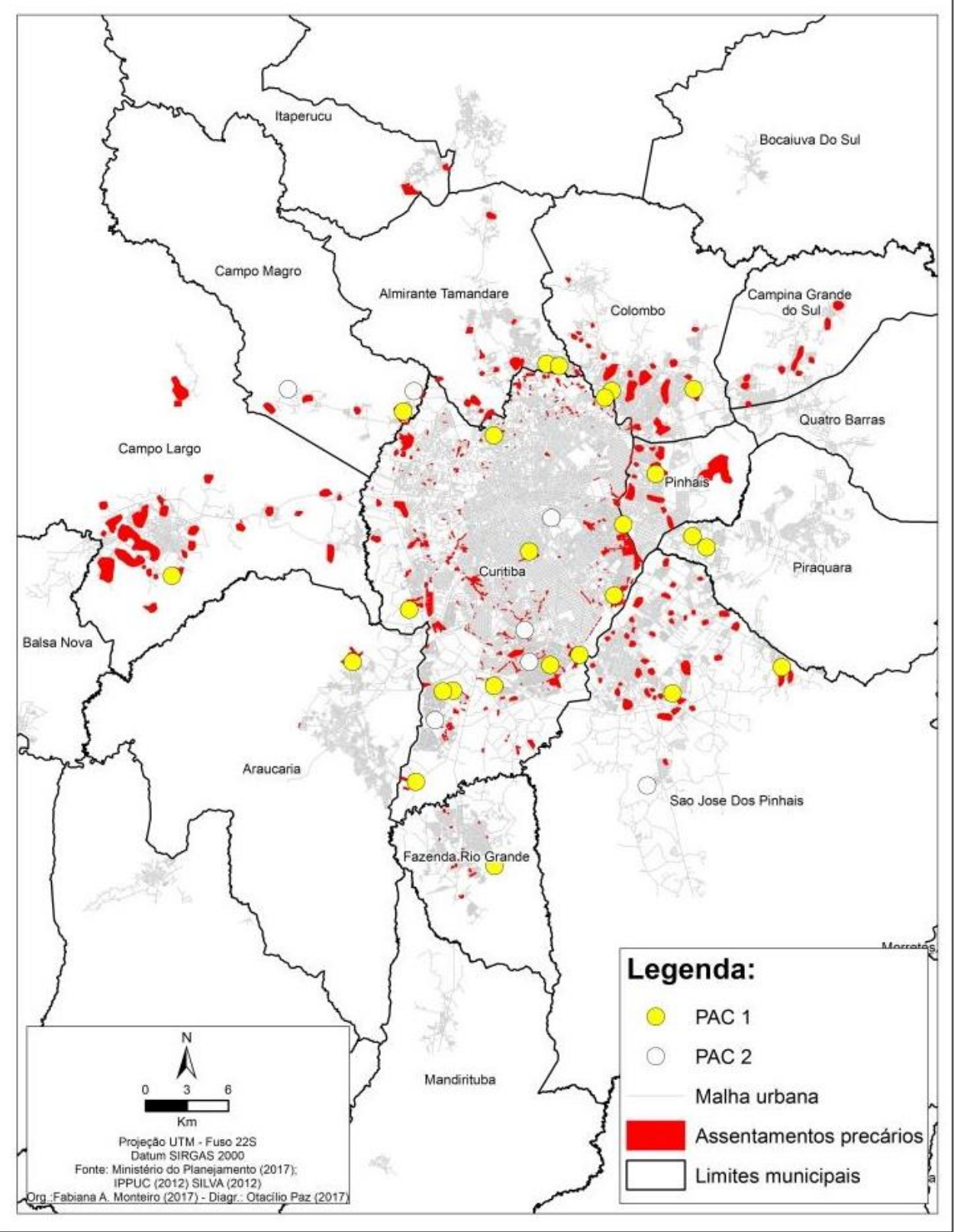

Fonte: BRASIL (2017); IPPUC (2012); SILVA (2012).

Elaboração: A autora; Otacílio Paz (2017). 
Figura 2 - Localização dos empreendimentos do PAC Habitação em Curitiba



Fonte: BRASIL (2017); IPPUC (2012)

Elaboração: A autora; Otacílio Paz (2017).

A partir da análise dessas Figuras depreende-se que estes empreendimentos do PAC Habitação, atualmente em curso na RMC são irrisórios perante a demanda por moradia existente. Além disso, cabe ressaltar que a literatura especializada aponta muitas limitações neste Programa, como a padronização dos empreendimentos por todo o país e o fato dos Projetos não preveem a inclusão social e o envolvimento da população local na sua execução.

Ademais, constatou-se nessa pesquisa que a maioria dos assentamentos tanto em Curitiba, como nos municípios no seu entorno, estão localizados em APPs ou em áreas 
de mananciais, portanto, configurando uma situação de risco permanente. Tendo em vista aqui, a distinção conceitual que Souza (2015) faz entre espaços que apresentam risco e espaços que representam risco. De acordo com o autor, o primeiro se refere aos espaços que dentro dos seus limites comporta ou tende a comportar processos e dinâmicas que acarretarão um risco de catástrofe ou desastre para as pessoas que vivem ou trabalham naquele local. Sendo estes espaços geralmente discriminados, segregados e estigmatizados, isso porque, segundo o autor, dão testemunho de uma situação de injustiça ambiental. Já os espaços que representam risco, seriam aqueles que constituem um risco para o próximo em função das atividades e dinâmicas que lá ocorrem, estando ainda associados a pessoas e seus modos de vida. Souza destaca também que, ironicamente, o 'risco' que representa uma ocupação formal do espaço relacionada à poluição e ao desmatamento, é em geral, subestimado e tratado como necessário ao 'progresso e ao desenvolvimento', enquanto o 'risco' representado por uma favela/assentamento constitui uma 'agressão ao meio ambiente (SOUZA, 2015, p.30).

\section{Condições de Moradia e do Meio Ambiente nos assentamentos de Campo Magro, Colombo e Piraquara}

Os municípios analisados nesse trabalho foram os primeiros da RMC a terem assentamentos precários selecionados para passarem por intervenção do poder público através PAC Habitação. Além desse aspecto em comum, apresentam histórico de ocupação semelhante, bem como a problemática da moradia e do meio ambiente em seus territórios são similares. Especialmente Colombo e Piraquara que tiveram aumento populacional significativo a partir da década de 1970 e durante os anos de 1990 passaram por um processo de intensificação no número de famílias residindo em áreas inadequadas à moradia.

De acordo com os estudiosos da metrópole de Curitiba, esse período é caracterizado por grandes transformações no Paraná, com uma intensa migração ruralurbana, cujo destino principal era a capital do estado e municípios limítrofes. (FIRKOWISKI, 2001; LIMA, 2000, 2001; MOURA \& RODRIGUES, 2009). Esse contexto aliado a outros fatores, como a crise econômica do país na década de 1980, o aumento nos preços do solo urbano e de suas regulamentações, além da desigualdade social, resultou também em um aumento considerável no número de famílias residindo irregularmente em locais impróprios à moradia.

Todavia, Maricato (2000) afirma que a "tragédia urbana do Brasil" não é produto das décadas perdidas e tem suas raízes em cinco séculos de formação da sociedade brasileira, especialmente a partir da privatização da terra (1850) e da emergência do trabalho livre (1888). Portanto, de acordo com a autora, o crescimento urbano do Brasil sempre ocorreu com a exclusão social, fazendo com que grande parte da população, inclusive àquela regularmente empregada, construísse sua própria moradia em áreas irregulares ou "simplesmente invadidas" (MARICATO, 2000, p.4).

Levando em consideração esse cenário, este trabalho analisa justamente assentamentos da RMC, formados entre o final dos anos de 1980 e início da década de 1990 e que estão localizados em áreas de mananciais de abastecimento público, APPs, fundos de vale e faixas de domínio de rodovias. Tal condição caracteriza esses espaços como aqueles que apresentam risco, conforme a definição de Souza (2015), pois estas famílias estão sujeitas a enchentes, deslizamentos e contaminação por doenças relacionadas à falta de saneamento básico.

Além do mais, as condições que estas famílias vivem podem contribuir para o comprometimento da qualidade dos cursos de água e o solo, pois, conforme o Plano 
Diretor de Piraquara de 2006, a insuficiência da rede coletora de esgoto causa a contaminação das águas subterrâneas e dos corpos hídricos da região (PIRAQUARA, 2006).

Tal situação era mais grave na UTP do Guarituba, onde, segundo a COHAPAR, mais da metade dos 44 mil habitantes da área no ano de 2007 não eram atendidos pelos serviços de abastecimento de água e rede de esgoto e havia inúmeras ligações clandestinas de energia elétrica. Além disso, das 32 mil pessoas inseridas na área selecionada para passar por intervenção, 24 mil estavam em condição irregular, ou seja, sem o título da posse da terra, num ambiente caracterizado pela fragilidade ambiental em função do predomínio de solos hidromórficos e do lençol freático aflorante. Este solo possui baixa capacidade de drenagem e mesmo após a implantação do canal extravasor do Rio Iguaçu, ainda existem problemas relacionados à drenagem o que favorece alagamentos e prejuízos à população local (COHAPAR, 2007).

Entre esses municípios selecionados para passar por intervenção, Campo Magro é o mais jovem e o que possui menor população total (Tabela 1). Uma das suas peculiaridades é o fato de que $100 \%$ do seu território é Área de Proteção Ambiental, sendo inserido em parte na APA do Passaúna, que integra também os municípios de Almirante Tamandaré, Araucária, Campo Largo e Curitiba. Por esta razão, recebe royalties de preservação ambiental, que é a principal fonte de renda do município.

Conforme aponta o Plano de Recuperação Ambiental e Urbanização do município, existem 18 assentamentos precários localizados em áreas de risco e de preservação permanente. Destes, foram selecionados seis no Jardim Cecília e Jardim Boa Vista para fazerem parte do Projeto de Urbanização do Passaúna. Sendo que estas áreas foram ocupadas no ano de 1993 por 430 famílias que desde então, passaram a viver em condição de risco e extrema precariedade (COHAPAR, 2015).

Com o intuito de traçar o perfil socioeconômico desses moradores, a Companhia de Habitação do Paraná realizou um cadastramento socioeconômico da população no ano de 2007 em parceria com a Prefeitura Municipal. Este cadastramento serviu de base para a elaboração do Projeto de Intervenção que definiu as seis áreas onde as famílias que viviam em situação de risco deveriam ser removidas e as quatro áreas de relocação destinadas a abrigar as unidades habitacionais. Este Projeto definia ainda que essas áreas degradadas deveriam passar por recuperação ambiental e que consistia basicamente na construção de parques de lazer nas áreas de risco, após a relocação das famílias. Além da regularização fundiária desses assentamentos, ou seja, possibilitar a garantia da posse da terra aos moradores. Entretanto, cabe ressaltar que de acordo com o Instituto Pólis (2002), a regularização fundiária poderia prever também a integração dos assentamentos à malha urbana, pois a mera distribuição de títulos da terra sem uma melhoria significativa nas condições urbanísticas pode ter efeitos negativos para a cidade e para a própria população envolvida.

As demais propostas desse e dos demais Projetos encontram-se no Quadro 3 a seguir. 


\begin{tabular}{|c|c|c|c|}
\hline & Campo Magro & Colombo & Piraquara \\
\hline Empreendimento & Urbanização Passaúna & Urbanização Roça Grande & Urbanização Guarituba \\
\hline Investimento: & $\mathrm{R} \$ 13,2$ milhões & R\$ 20,6 milhões & R\$ 105,2 milhões \\
\hline Fonte: & OGU & OGU & OGU \\
\hline $\begin{array}{l}\text { Famílias a serem } \\
\text { beneficiadas: }\end{array}$ & 430 & 879 & 8.890 \\
\hline Problemática: & $\begin{array}{l}\text { Assentamentos em área de } \\
\text { mananciais; Contaminação } \\
\text { Rio Passaúna. }\end{array}$ & $\begin{array}{c}\text { Assentamentos nas margens } \\
\text { da BR } 116 \text { e dos Rios } \\
\text { Palmital, Arruda e Atuba. }\end{array}$ & $\begin{array}{l}\text { Assentamentos em área de } \\
\text { mananciais de abastecimento } \\
\text { de água da RMC. }\end{array}$ \\
\hline $\begin{array}{l}\text { Ações de } \\
\text { Infraestrutura: }\end{array}$ & $\begin{array}{c}\text { Pavimentação; adequação } \\
\text { da rede de esgoto; } \\
\text { instalação de energia } \\
\text { elétrica e eq. urbanos. }\end{array}$ & $\begin{array}{l}\text { Pavimentação; adequação da } \\
\text { rede de esgoto; instalação de } \\
\text { energia elétrica e eq. } \\
\text { urbanos. }\end{array}$ & $\begin{array}{l}\text { Pavimentação, adequação da } \\
\text { rede de esgoto; instalação de } \\
\text { energia elétrica e eq. } \\
\text { urbanos; macro e } \\
\text { microdrenagem; }\end{array}$ \\
\hline $\begin{array}{l}\text { Regularizações } \\
\text { Fundiárias: }\end{array}$ & 42 & 371 & 8.087 \\
\hline $\begin{array}{l}\text { Construção de } \\
\text { U. H.: }\end{array}$ & 388 & $\begin{array}{c}\text { - } 70 \text { Jd. Contorno } \\
\text { - } 188 \text { no Jd. Marambaia } \\
\text { - } 234 \text { na Vila Liberdade } \\
\end{array}$ & 803 \\
\hline $\begin{array}{l}\text { Recuperação } \\
\text { ambiental: }\end{array}$ & $\begin{array}{c}\text { Implantação de quatro } \\
\text { parques de lazer. }\end{array}$ & $\begin{array}{l}\text { Implantação de três parques } \\
\text { de lazer. }\end{array}$ & $\begin{array}{c}\text { Implantação de quatro } \\
\text { parques de lazer. }\end{array}$ \\
\hline
\end{tabular}

Quadro 3 - Síntese das propostas dos Projetos de Urbanização analisados

Fonte: COHAPAR $(2007 ; 2012 ; 2015)$.

Elaboração: A autora (2018).

Este cadastramento socioeconômico também foi realizado com as famílias dos assentamentos selecionados de Colombo e Piraquara e de forma geral, as informações coletadas nos três municípios identificaram que esta população era predominantemente de baixa renda, com mais de dois terços das famílias recebendo até três salários mínimos e que possuíam baixa escolaridade, como no Jardim Contorno, por exemplo, onde $68 \%$ da população possuía apenas o Ensino Fundamental. As informações apontaram também uma grande quantidade de jovens: mais de $60 \%$ da população do Jardim Marambaia tinha até 30 anos de idade e que mais de $70 \%$ das famílias da Vila Liberdade e do Guarituba possuíam mais de três membros. Além disso, de acordo com estes diagnósticos, grande parte destes chefes de famílias estavam inseridos no mercado de trabalho informal e a maioria residiam nesses locais há mais de dez anos (COHAPAR, 2007, 2012, 2015).

$\mathrm{O}$ fato de esses dados evidenciarem que estes assentamentos são formados por famílias predominantemente de baixa renda, com baixo nível de escolaridade e sem qualificação profissional, indica a dificuldade ou mesma impossibilidade das mesmas adquirirem um imóvel nos moldes estabelecidos pelo mercado imobiliário formal, havendo necessidade, portanto, do suporte do Estado para facilitar o seu acesso à moradia digna.

Em relação ao município de Colombo, caracteriza-se como o mais populoso entre os três e o que apresenta também as piores condições de moradia e preservação do Meio Ambiente e esta situação é mais evidente nos assentamentos da Vila Liberdade e do Jardim Contorno. Ao todo, existem no município 59 assentamentos precários localizados principalmente nos limites da área urbana com a capital e que se formaram, sobretudo no início da década de 1990 (COLOMBO, 2012). É o caso da Vila Zumbi dos Palmares, urbanizada no ano de 2004, configurando então um dos primeiros assentamentos a passar por intervenção do poder público fora dos limites da capital. Este assentamento, com um histórico de ocupação muito semelhante ao do Guarituba em Piraquara, apresentava um quadro pobreza e precariedade extrema e foi durante muito tempo uma das maiores favelas da RMC. 
Quanto aos assentamentos analisados neste município, o do Jardim Marambaia está localizado na margem direita do Rio Atuba, num fundo de vale remanescente de um loteamento regular aprovado em Área de Preservação Permanente. Sua ocupação ocorreu na primeira metade da década de 1990 por cinco famílias oriundas do interior do estado e posteriormente outras famílias foram se instalando na área (COHAPAR, 2012).

Já a Vila Liberdade está localizada ao sul do município de Colombo, nos limites com Pinhais e o assentamento aí presente se estende ao longo da Área de Preservação do Rio Palmital, pela faixa de domínio da BR 116 e em áreas particulares. De acordo com Ritter (2011) a Vila Liberdade foi formada a partir de três diferentes formas de apropriação do solo urbano: através da aquisição legal de terrenos nas áreas loteadas pela AZ Imóveis, o que corresponde a um número pequeno de moradores; pela ocupação de lotes legalizados ou por sua aquisição legal, mas que, com o passar do tempo e conforme se multiplicarão as ocupações, deixaram estes lotes de serem pagos e tornaram-se irregulares. E a terceira forma de ocupação se deu através dos assentamentos informais que se estabeleceram a partir da segunda metade da década de 1980. Estes assentamentos se concentraram em porções dos três loteamentos realizados pela AZ Imóveis, a do Jardim Graciosa, da Vila Palmital e da Vila Ana Maria, a esquerda do Rio Palmital (RITTER, 2011).

Sobre a situação da várzea do Rio Palmital que corta o município de Colombo de norte a sul na sua área mais urbanizada, Lima (2001, p.101), afirma que ela foi progressivamente ocupada desde a década de 1970, o que a tornou num "manancial que, constantemente beira os limites mínimos aceitáveis de uso para abastecimento" e num foco de contaminação para outros braços da rede.

Ademais, a problemática da moradia e do Meio Ambiente em Colombo e especificamente na Vila Liberdade parece agravar-se a cada dia, pois, foi constatado em visita de campo ao local, um recente foco de ocupação localizado logo na entrada da Vila, num terreno próximo ao Rio Palmital e que conta já com várias sub habitações e não possui nenhum tipo de infraestrutura (Figura 3). Contudo, a precariedade de infraestrutura e de serviços não é característica apenas dos assentamentos, todo o território da Vila Liberdade, inclusive os lotes que foram adquiridos legalmente na década de 1980, são marcados pela ausência de asfaltamento e presença de esgoto a céu aberto em algumas localidades, entulhos em terrenos baldios e contaminação dos cursos d'água também através do lixo descartado irregularmente. A Figura 3 a seguir demonstra respectivamente parte desse novo assentamento e a infraestrutura precária da Vila Liberdade.

Figura 3 - Condições de moradia e de infraestrutura da Vila Liberdade/Colombo
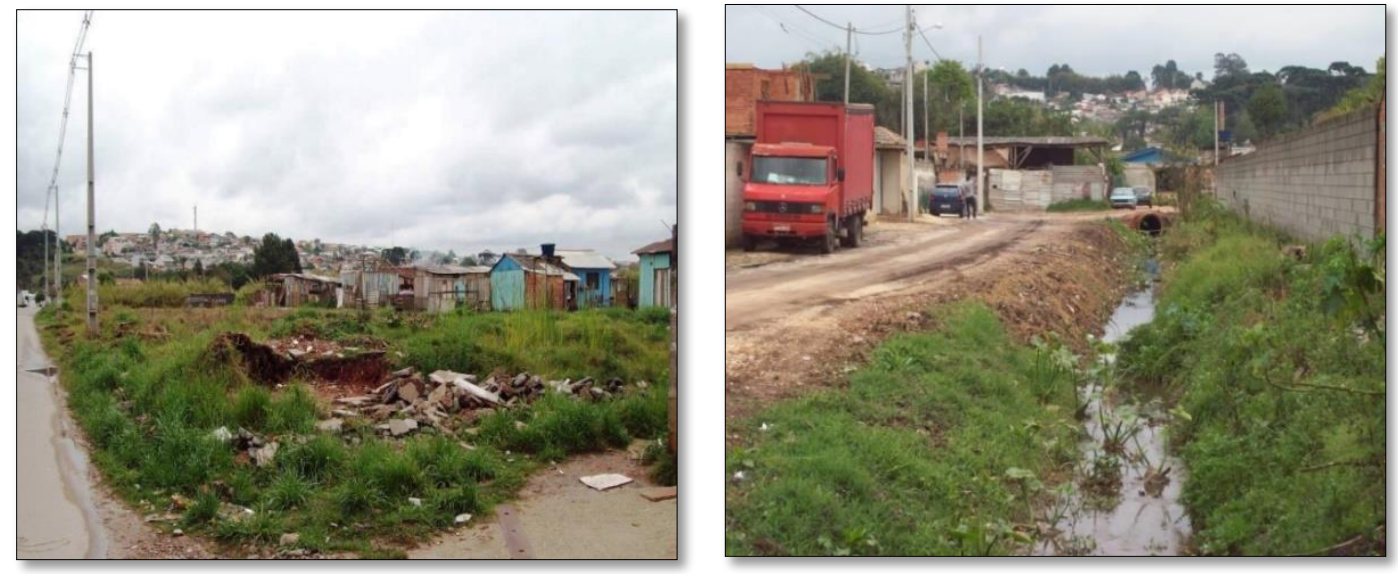

Fonte: A autora (2016) 
No Jardim Contorno as condições de moradia e infraestrutura são ainda mais deficientes, bem como é maior a situação de risco em que vivem as famílias e a fragilidade do Meio Ambiente. Localizado na APP do Ribeirão Arruda, entre a faixa de domínio da PR 418 e os limites do Jardim Cezar Augusto, o assentamento está situado a sudoeste do município de Colombo. Foi identificado em visita de campo à localidade que o mesmo não dispõe de vias regulares e o acesso às moradias ocorre através de vielas em meio à vegetação densa e aos entulhos. Também não há tratamento de esgoto e a rede de energia elétrica e de água ou é deficiente ou é clandestina. A situação de risco que estas famílias estão submetidas é em parte demonstrada na Figura 4 a seguir.

Figura 4 - Condições das moradias no Jardim Contorno/Colombo
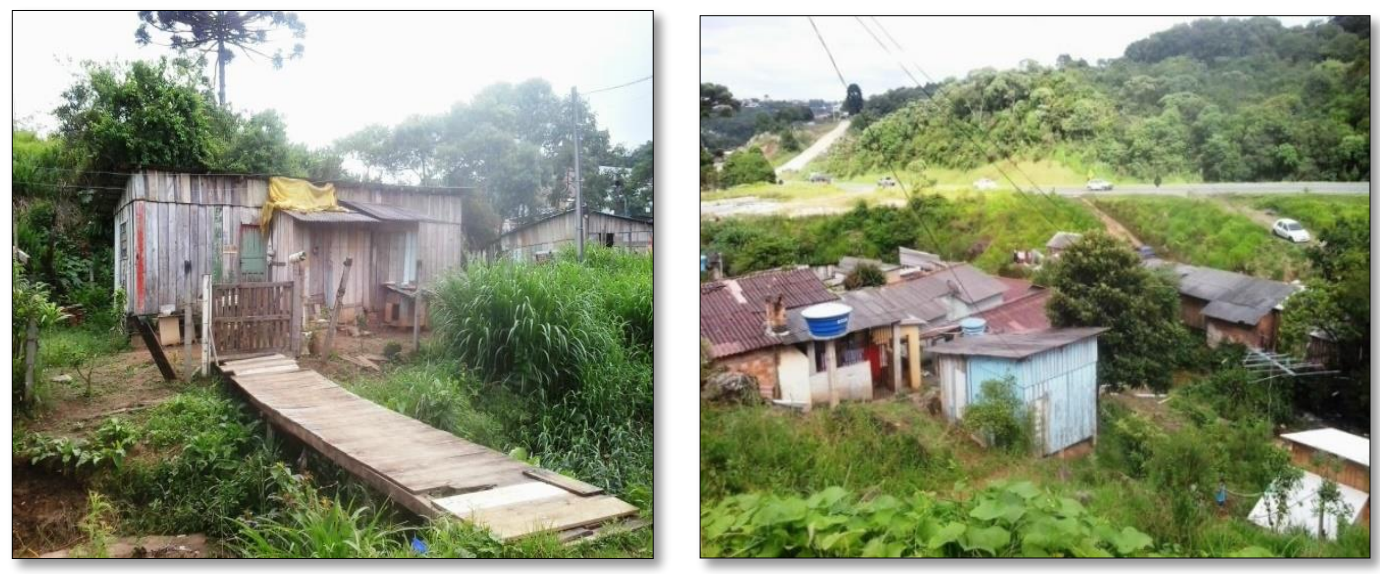

Fonte: A autora (2016)

No que se refere ao município de Piraquara, sua origem está relacionada aos pequenos arraiais de mineração e fazendas oriundas do processo de subdivisão de sesmarias do Brasil Colônia. Com a construção da Estrada de Ferro Paranaguá-Curitiba na década de 1880, a região aonde veio a se formar o município se beneficiou com a construção de uma estação ferroviária que proporcionou o seu desenvolvimento (PIRAQUARA, 2006).

Entretanto, o seu período de maior crescimento populacional ocorreu a partir de 1970, com o processo de metropolização de Curitiba. Nessa década, com a elaboração do Plano de Desenvolvimento Integrado (PDI) da RMC em 1978, já se estipulava para Piraquara, incorporada então ao que se chamou de "Subsistema Leste", juntamente com Campina Grande do Sul, Quatro Barras e posteriormente Pinhais, uma proposta de ordenamento territorial, cuja premissa era limitar a densidade populacional, dada a capacidade de esgotamento sanitário e drenagem das áreas de mananciais destes municípios, ao mesmo tempo em que se previa o apoio a suas atividades rurais. Essa limitação ao crescimento populacional no município e, sobretudo na área de mananciais do Guarituba, também foi prevista no Plano Diretor de Piraquara de 1980 (COMEC, 2006).

Ainda assim, nas décadas seguintes há uma continuidade no processo de informalidade e precarização da moradia no município e especialmente no Guarituba que foi formada entre o fim dos anos de 1980 e início da década de 1990.

Conforme atestam Lima, Campos e Terbeck (2009), o Guarituba constitui uma área de ocupação urbana significativa do município, superando a sede urbana em expansão, dada a influência da Estrada do Encanamento e da linha férrea. Caracteriza-se ainda pela presença de inúmeras subhabitações e por sua fragilidade ambiental, em função do predomínio de solos hidromórficos e do lençol freático aflorante, como se poderá observar na Figura 5. Além disso, muito do seu expressivo crescimento populacional se 
$\overline{\text { deve, segundo os autores, as vias de fácil acesso a capital e sua proximidade ao município }}$ de Pinhais, que até o ano de 1992 foi Distrito de Piraquara.

A emancipação de Pinhais resultou, de acordo com os autores, em profundas transformações socioeconômicas em Piraquara, culminando com uma perda de " $21 \%$ do seu território e $71 \%$ da sua população". No entanto, mesmo com essa perda populacional, o município apresentou no período entre 1996 a 2000 uma taxa de crescimento anual de 8,53\%, uma das maiores da RMC (LIMA; CAMPOS; TERBECK, 2009, p. 274).

A partir da elaboração do novo Plano Diretor de Piraquara em 2006, a UTP do Guaritiba foi incorporada ao perímetro urbano do município, em razão das suas atuais características e necessidades. Um novo zoneamento também foi proposto para a área, devido à contínua degradação ambiental e aumento da densidade populacional.

Ainda assim, no momento da elaboração do Diagnóstico Físico e Socioeconômico da UTP do Guarituba, a COHAPAR (2007) estimava que 24.000 dos 44 mil habitantes da área estavam vivendo irregularmente em precárias condições de moradia em função da deficiência de infraestrutura e equipamentos públicos. A Companhia afirma também que predomina no Guarituba o uso habitacional, havendo pontos de comércio varejista de pequeno porte ao longo das principais vias, sendo que a ocupação desordenada dificulta a circulação na área, em razão da malha viária ser parcial e descontínua. Dessa forma, o Projeto elaborado para a UTP previa a implantação de infraestrutura básica, a construção de mais de 800 unidades habitacionais e 4 parques de lazer e, a obtenção do título da terra para mais de 8 mil famílias (COHAPAR, 2007).

Desse modo, desde o ano de 2007 o poder público vem implementando a intervenção que tem resultado em algumas transformações e que consistem basicamente na relocação das famílias das áreas de risco para os dois conjuntos habitacionais previstos, a adequação da infraestrutura em pontos específicos e a recuperação parcial do meio ambiente. Todavia, essa urbanização não está prevista para todo o território da UTP que ainda sofre com a pressão por ocupação, sobretudo irregular, dada a sua proximidade com a capital e ao baixo valor dos lotes (GAZETA DO POVO, 2010).

Maiores informações sobre as atuais condições socioambientais da UTP do Guarituba e dos demais assentamentos de Campo Magro e Colombo serão analisados no próximo item.

Figura 5 - Condições do Meio Ambiente e da moradia na UTP do Guarituba em 2007
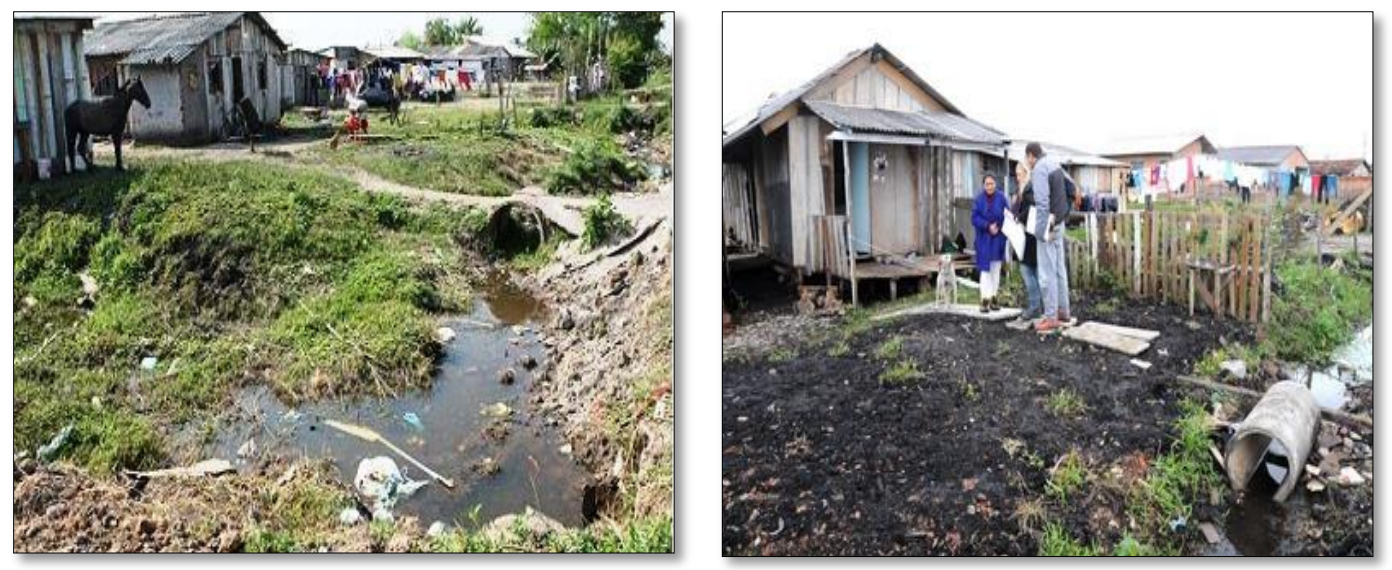

Fonte: COHAPAR (2007) 
Meio ambiente e moradia nos assentamentos selecionados a partir da intervenção do poder público

Em relação aos resultados prévios da intervenção que ocorre no município de Campo Magro, que é menos abrangente e, portanto demandou menor volume de recursos em relação aos demais, encontrava-se no momento da pesquisa num estágio relativamente avançado, com 98\% de conclusão (BRASIL, 2017a). Todavia, cabe ressaltar que o prazo previsto inicialmente para a conclusão das obras era o ano de 2011. Entre as ações previstas no Projeto, foram concluídas as propostas de implantação de infraestrutura básica nas áreas selecionadas, com pavimentação, instalação ou adequação da rede de energia elétrica, de água e de esgoto. Também ocorreu a relocação das famílias que residiam em situação de risco para unidades habitacionais do Programa e as mesmas estão inseridas em quatro áreas de relocação ao longo dos Jardins Cecília e Boa Vista. Já a proposta de regularização fundiária, estava em andamento, assim como a de recuperação ambiental que havia sido parcialmente concluída, restando ainda concluir a implantação de três dos quatro parques de lazer previstos. (BRASIL, 2017a; COHAPAR, 2015).

Já as atuais condições de moradia das famílias envolvidas neste e nos demais Projetos de Intervenção e a situação do Meio Ambiente que são esboçadas brevemente aqui, foram realizadas com base em observações de campo e entrevistas com as famílias relocadas para os conjuntos habitacionais, além de comparação com as condições dos assentamentos antes das intervenções, descritas nos Projetos elaborados pela COHAPAR.

Dessa forma, comparando as condições dos assentamentos analisados de Campo Magro anteriores à implementação do Projeto (Figura 6) com a situação pós intervenção (Figura 7), é possível observar que houve alguns melhoramentos na área, como a instalação/adequação de infraestrutura mínima, construção de unidades habitacionais fora das áreas de risco para as famílias selecionadas e melhoria parcial no padrão das construções. Além disso, até o momento das visitas de campo na área de intervenção, constatou-se que apenas um dos parques de lazer havia sido instalado em um dos locais previstos, entretanto, foi possível perceber que o local não contava até então com uma manutenção adequada (Figura 7).

Ademais, com base na análise do Projeto elaborado para a área, pode-se dizer que a recuperação ambiental prevista para estes assentamentos de Campo Magro é parcial e restrita a alguns pontos mais críticos dos bairros. Sobretudo após observar em visita de campo que ainda existem no local muitos vazios urbanos que são carentes de infraestrutura, muitos dos quais, localizados próximos a fundos de vale e APPs, e que podem constituir, portanto, novos locais de assentamentos no futuro.

E, como o Projeto para estes assentamentos não possui diretrizes que visam à inclusão social ou melhoria nas condições de vida das famílias, pode se dizer que as transformações ocorridas nos mesmos são insuficientes para alterar substancialmente o seu quadro socioeconômico. 


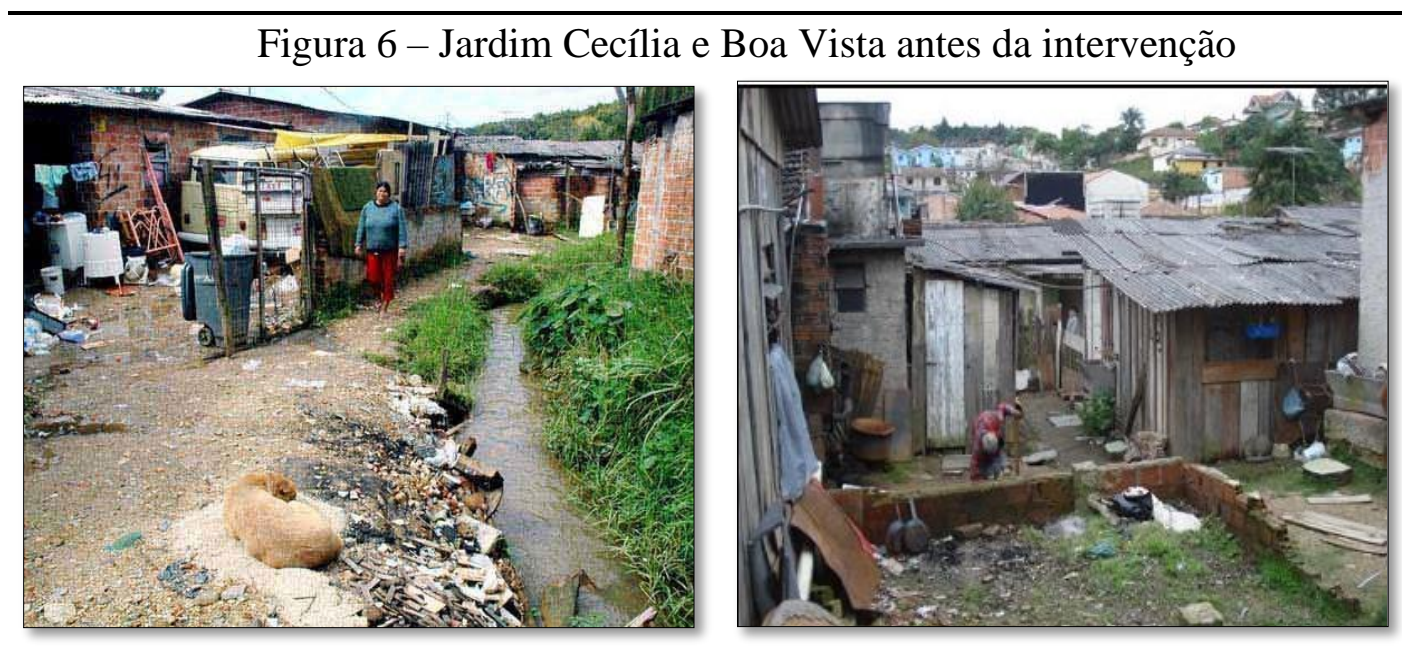

Fonte: COHAPAR (2015)

Figura 7 - Parque Ambiental e unidade habitacional do Projeto de Campo Magro
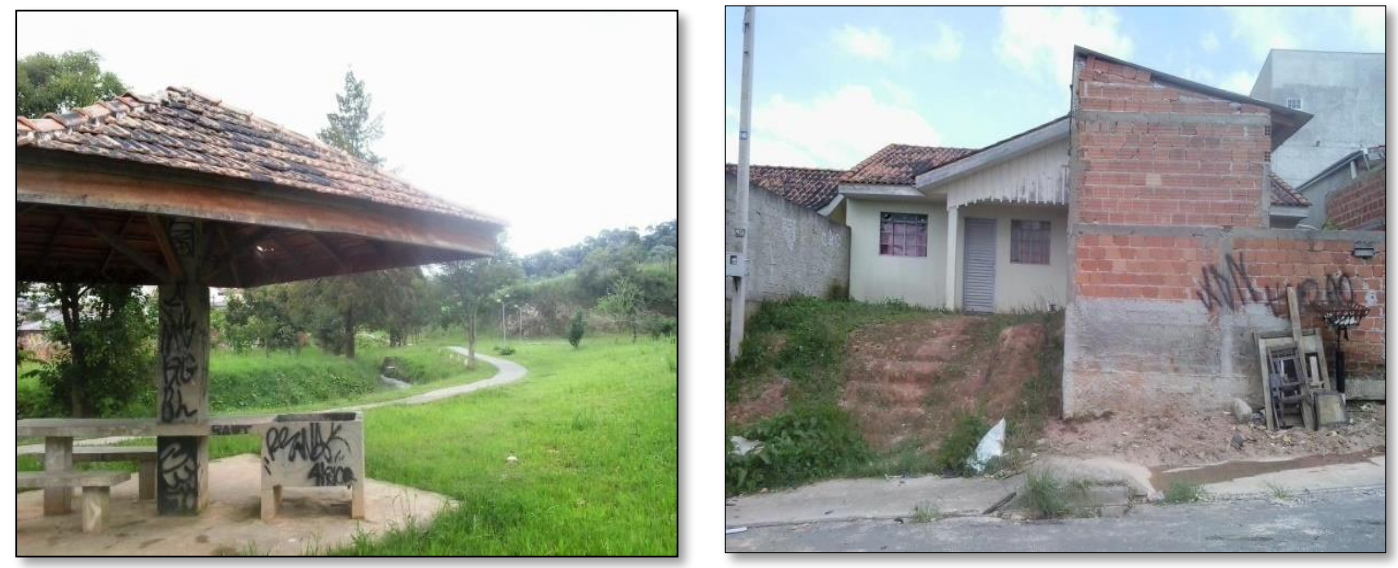

Fonte: A autora (2016).

Quanto ao Projeto Roça Grande elaborado para o município de Colombo, encontrava-se paralisado e com apenas 57\% das ações executadas (BRASIL, 2017a). Dos três assentamentos, apenas o do Jardim Marambaia (Figura 8) tinha concluído a etapa de implantação de infraestrutura básica e de relocação das famílias das áreas de risco para o conjunto habitacional. Já o processo de regularização fundiária estava em andamento e a recuperação ambiental havia sido parcialmente executada, consistindo na retirada das sub habitações da APP do Rio Atuba e implantação no local de um parque de lazer (COHAPAR, 2012; COLOMBO, 2016). 


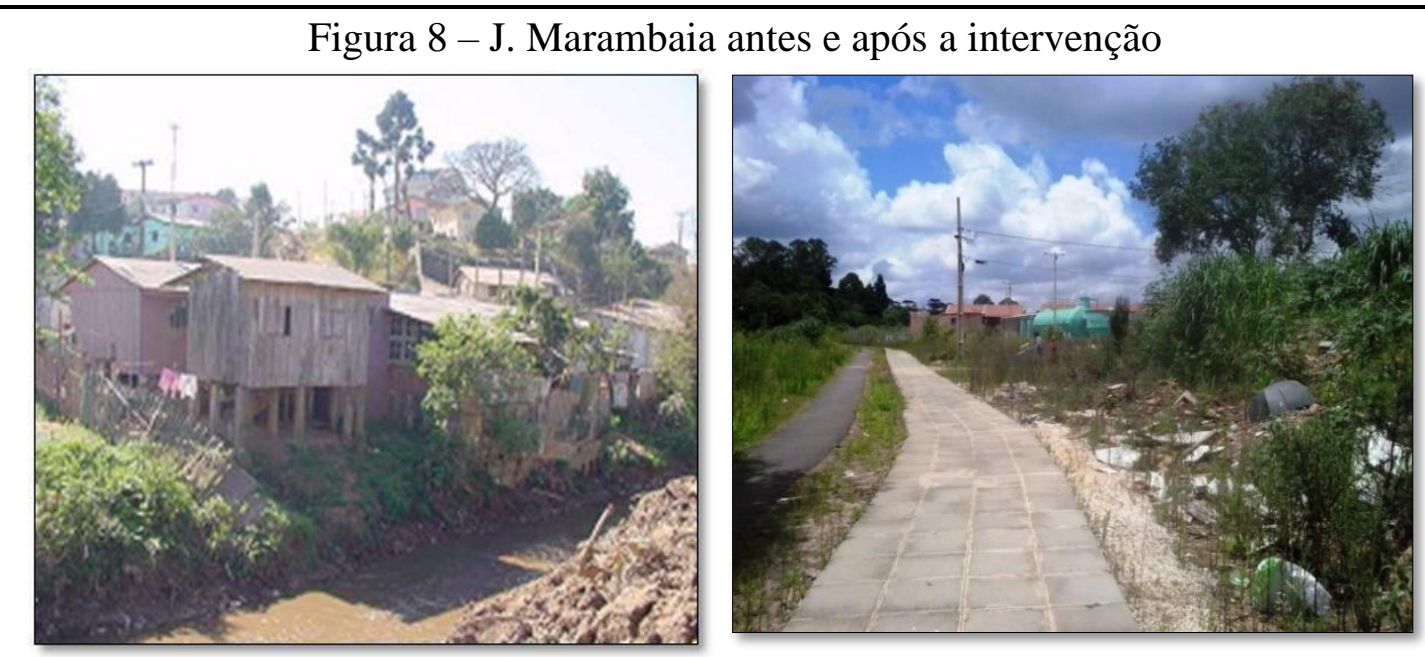

Fonte: COHAPAR (2012); A autora (2016).

Já as visitas de campo à Vila Liberdade e ao Jardim Contorno revelaram, no entanto, que nesses assentamentos o Projeto de Intervenção não saiu do papel. Conforme se pode verificar nas Figuras 9 e 10 a seguir, não houve implantação de infraestrutura na área, tampouco houve relocação das famílias que viviam em situação de risco e precariedade para novas unidades habitacionais previstas no Projeto. A recuperação ambiental também não havia sido executada e estes assentamentos continuavam sem rede de coleta e tratamento de esgoto, contribuindo para a contaminação dos cursos de água que permeiam estes locais e consequentemente, podem ocasionar vários tipos de doenças, além de causarem prejuízos matérias a estas famílias em caso de enchentes e inundações.

\section{Figura 9 - Vila Liberdade/Colombo}
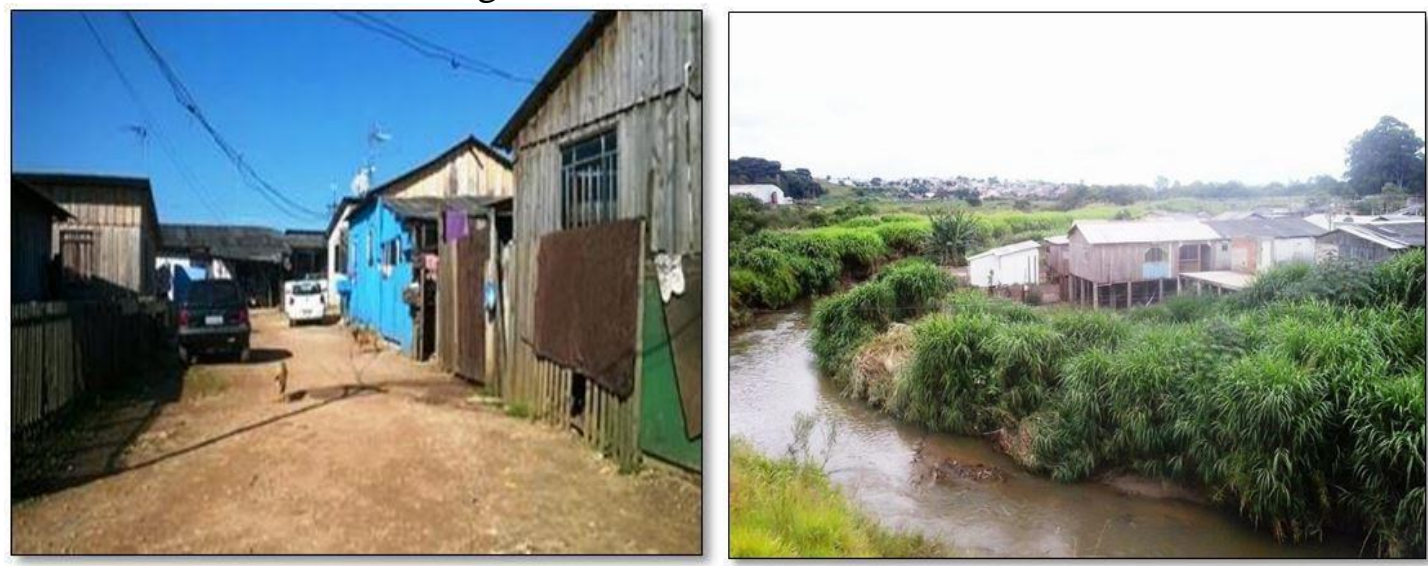

Fonte: A autora (2016). 


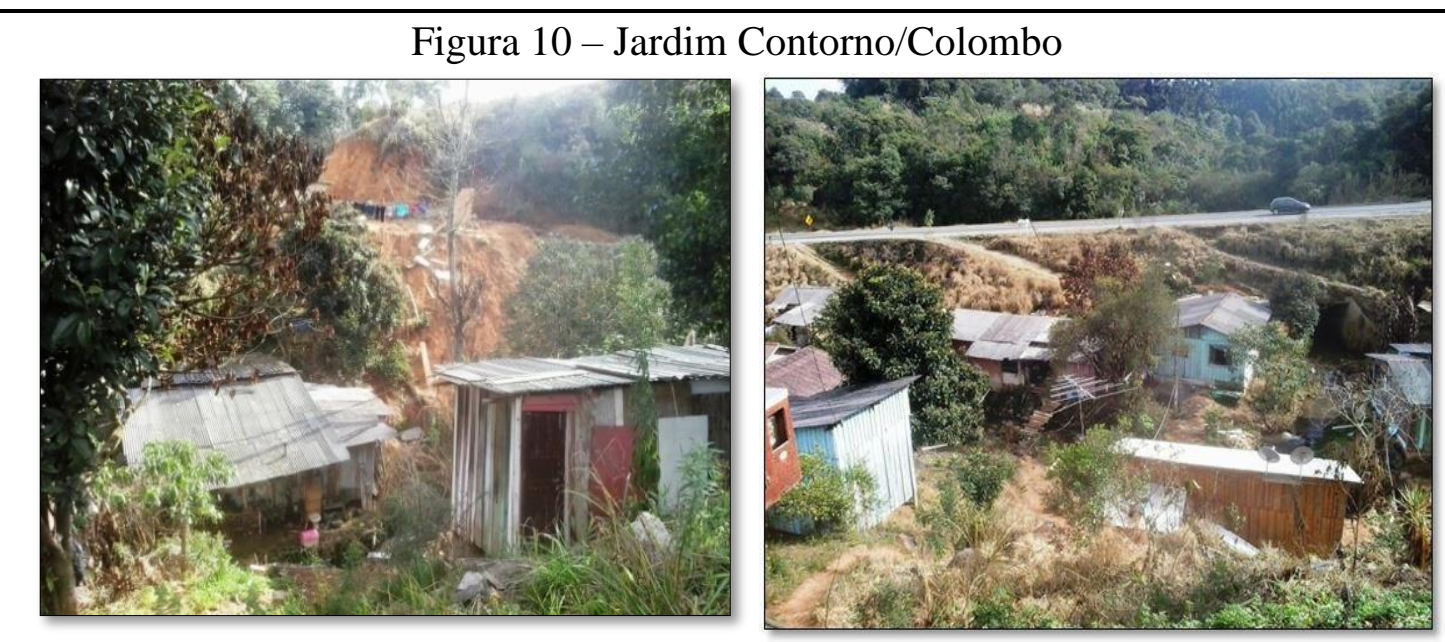

Fonte: A autora (2016)

Ademais, a partir das observações realizadas no Jardim Marambaia, parcialmente exposta na Figura 8, foi possível verificar que mesmo nesse assentamento, o único do Projeto Roça Grande que havia sido urbanizado até então, a recuperação ambiental tinha sido executada de forma parcial, havendo ainda na APP do Rio Atuba, entulhos pertencentes às antigas moradias que foram demolidas e lixo doméstico que estava sendo descartado irregularmente no local. E, conforme o depoimento de alguns dos moradores do conjunto habitacional coletados em pesquisa de campo, a iluminação pública do local era precária, o que contribuía para a sensação de insegurança.

Como justificativa para o atraso/paralização da intervenção nestes assentamentos de Colombo, a Prefeitura Municipal havia apontado para a burocracia enfrentada no processo de licitação, a falta de recursos financeiros para adquirir os terrenos destinados a abrigar os conjuntos habitacionais, as dificuldades em desapropriar as famílias das áreas de risco e a dificuldade em convencer as mesmas a serem relocadas para um local mais distante (COLOMBO, 2016).

Fatores similares aos mencionados aqui e que tem culminado em entraves na execução das intervenções do PAC Habitação por todo o país foram discutidas por Campanhoni (2016) em sua pesquisa realizada com a equipe do Departamento de Urbanização de Assentamentos Precários, da Secretaria Nacional de Habitação. Nesta pesquisa a autora apresenta alguns dos fatores relacionados à morosidade na implementação do Programa UAP, na sua primeira fase (2007-2009), como a falta de conhecimento e equipe técnica especializada nas Prefeituras Municipais; as frequentes rescisões de contrato com as empresas contratadas; a demora nos processos licitatórios e de licenciamento ambiental e problemas com a titularidade das áreas (CAMPANHONI, 2016).

Quanto à intervenção no assentamento da UTP do Guarituba, também se encontrava em situação de atraso, com aproximadamente $60 \%$ de execução. As transformações ocorridas aí consistiam basicamente na relocação das famílias que residiam em áreas de risco para os dois conjuntos habitacionais previstos no Projeto e implantação de infraestrutura básica no mesmo. A etapa de regularização fundiária estava em andamento, assim como a recuperação ambiental, com a implantação de um dos parques de lazer em uma das áreas onde as famílias cadastradas haviam sido removidas. Segundo informações da Prefeitura do município, estava ocorrendo também à implantação/adequação de infraestrutura básica em outros pontos da UTP (BRASIL, 2017a, PIRAQUARA, 2016). 
Entretanto, deve-se ressaltar que a intervenção do poder público não tem sido capaz de trazer uma solução definitiva para a problemática da moradia na área, pois desde o início da intervenção no ano de 2007, há registro de novos focos de ocupação em pontos isolados da UTP, como nas proximidades da PR 415, por famílias que não haviam sido incluídas no Projeto, conforme levantamento realizado pelo principal Jornal de Curitiba ${ }^{6}$. A Figura 11 a seguir demonstra unidades habitacionais do conjunto habitacional Madre Teresa de Calcutá, para onde parte das famílias selecionadas pelo Projeto foram relocadas.

Figura 11 - Padrão das moradias da Intervenção do Guarituba/Piraquara
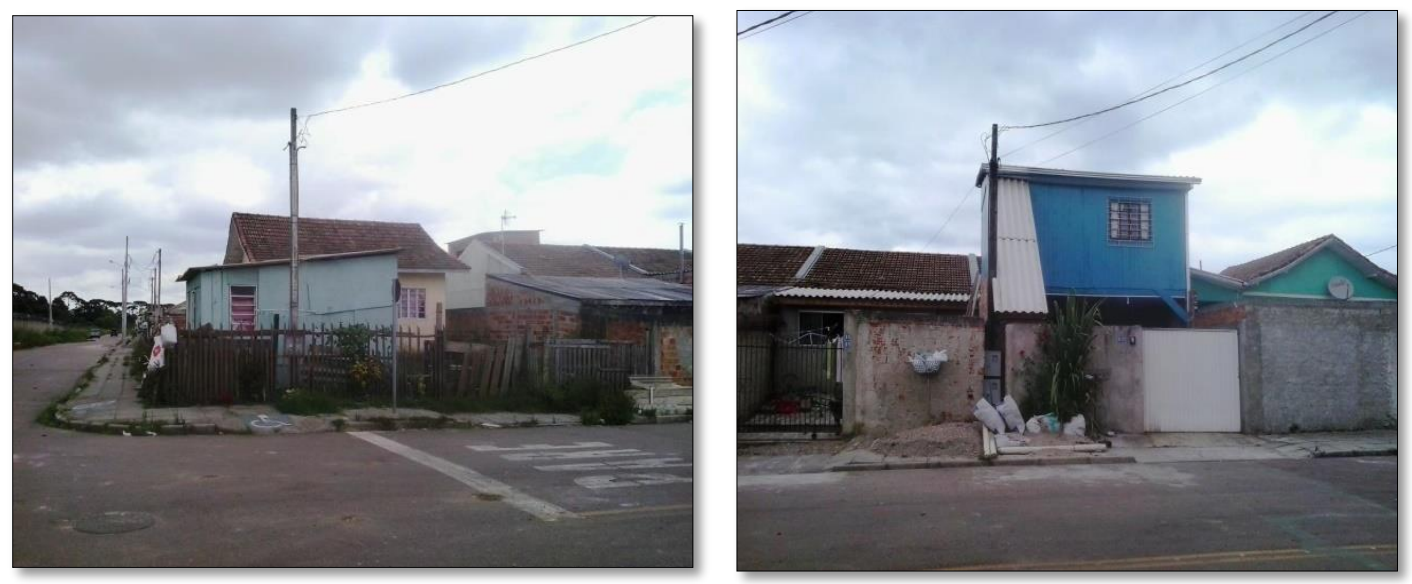

Fonte: A autora (2016).

Já as visitas de campo aos conjuntos habitacionais do Programa implementados na UTP do Guarituba e as entrevistas realizadas com parte das famílias relocadas para os mesmos, permitiram esboçar aqui, algumas considerações sobre as condições de moradia e do Meio Ambiente após a intervenção. Desse modo, foi possível verificar que a implantação/adequação da infraestrutura básica nos assentamentos contribuiu para melhorar em parte a situação de risco que as famílias estavam submetidas e de contaminação e degradação ambiental da área. Já a relocação de parcela dessa população para os conjuntos habitacionais contribuiu para uma relativa melhoria no padrão das moradias.

Todavia, tanto nos conjuntos habitacionais de Piraquara, quanto nos dos outros municípios analisados, a presença de um número cada vez maior de adaptações nas unidades habitacionais realizadas pelos próprios moradores, os chamados "puxadinhos" (Figura 11), demonstram que o padrão e o modelo adotado de moradia pelo Programa não têm atendido integralmente as necessidades dessas famílias.

Ademais, deve-se ressaltar que nesses assentamentos (com a exceção do Jardim Contorno e da Vila Liberdade em Colombo que não foram urbanizados), as melhorias implantadas se restringiram na maior parte dos casos, as áreas selecionadas pelo Projeto. Além disso, as entrevistas realizadas com parte dessas famílias relocadas para os conjuntos habitacionais demonstraram divergência de opiniões a respeito da intervenção promovida pelo poder público. Houve aqueles moradores que defenderam que a relocação das áreas de risco para uma unidade habitacional foi um avanço e que proporcionou melhoria nas condições de moradia. Enquanto que outros se mostraram insatisfeitos, tanto com a unidade habitacional, como com o novo local de residência, apontando como justificativa o padrão e a má qualidade do material utilizado na construção das moradias, além de terem mencionado a questão da violência que estava acometendo estes conjuntos habitacionais. Tal violência, segundo estes moradores, se relacionava, sobretudo ao 
tráfico de drogas e estava levando algumas dessas famílias a vender irregularmente o imóvel ou simplesmente a abandoná-lo.

\section{Considerações Finais}

A questão da moradia tem sido um dos maiores problemas do Brasil desde o início do século passado, presente principalmente nos grandes centros urbanos do país. De modo que Martins (2011), afirma que a desigualdade social faz com que a dificuldade de acesso à terra e a moradia digna ocupe um lugar central na abordagem sobre o espaço urbano. Sendo essa questão evidenciada por duas situações com características distintas: por um lado, o centro metropolitano valorizado, porém, obsoleto e em processo de abandono pelas camadas de alta e média renda, onde ocorrem as disputas territoriais entre a especulação imobiliária, a possibilidade de moradia a baixo custo e os projetos de renovação urbana que segregam a população local de menor renda. E, por outro lado, as franjas periféricas da metrópole, desvalorizadas e precárias, onde o conflito se manifesta entre a preservação do meio ambiente e a necessidade de moradia pela população pobre que acaba por se instalar em APPs e em áreas de mananciais.

Dessa forma, este trabalho teve como objetivo discutir a questão da moradia na periferia da metrópole de Curitiba e trazer um balanço prévio das transformações ocorridas em assentamentos de três municípios da RMC a partir da intervenção do poder público. Tal intervenção vem ocorrendo nesses locais desde o ano de 2007, através do Programa de Urbanização de Assentamentos Precários do PAC Habitação e está sendo executada pela COHAPAR em parceria com as Prefeituras Municipais. Tendo em vista as propostas de cada um destes Projetos, buscou-se averiguar que tipo de transformações vem ocorrendo no Meio Ambiente e nas condições de infraestrutura e de moradia desses assentamentos.

Como resultados da pesquisa, verificou-se que nos três municípios o prazo de conclusão já havia extrapolado em muito e as obras apresentavam diferentes estágios de execução. Dentre elas, a que se encontrava num estágio mais crítico era a Urbanização Roça Grande de Colombo, no qual, apenas um dos três assentamentos selecionados havia tido as propostas implementadas pelo poder público. Constatou-se também que os maiores entraves na execução desses Projetos diziam respeito à etapa de regularização fundiária e de recuperação ambiental e, nos poucos locais onde havia ocorrido essa recuperação, ela tinha sido parcial e insuficiente para promover melhorias significativas no Meio Ambiente.

Além do mais, as entrevistas com parte dos moradores relocadas para os conjuntos habitacionais do Programa revelou opiniões distintas. Houve aqueles que defenderam a intervenção e o novo local de moradia da mesma forma que foram identificados aqueles que se mostraram insatisfeitos e frustrados, sobretudo com o modelo adotado nas unidades habitacionais e a questão da violência que foi relatada por moradores dos conjuntos habitacionais dos três municípios.

Entretanto, apesar dos Projetos do Programa de Urbanização de Assentamentos Precários do PAC terem seguido um modelo padronizado e estarem muito aquém das reais necessidades da população pobre, além de haver muitos problemas relacionados à execução dessas intervenções ainda em andamento, este Programa teve sua relevância enquanto durou. Ainda que se saiba que a problemática da moradia requer ações muito mais incisivas por parte do Estado, como o controle do preço da terra, da especulação imobiliária e uma distribuição de renda mais justa entre a população.

De toda forma, no atual contexto de retrocesso social no país, em que muitas políticas públicas estão sendo abandonadas ou relegadas a segundo plano e, onde os 
recursos destinados a estes fins estão sendo cada vez mais escassos já há alguns anos, o maior desafio na atualidade é tornar a questão da moradia digna pauta novamente nas discussões da sociedade, buscando a partir daí, um aperfeiçoamento de programas habitacionais como o analisado, a fim de atender as reais necessidades da população de menor renda.

\section{Notas}

1 - Este trabalho apresenta parte dos resultados da Dissertação de Mestrado defendida pela autora no ano de 2016.

2 - O Sistema Financeiro da Habitação (SFH) consistia em um mecanismo de captação de poupança em longo prazo para investimentos no setor da habitação e tinha como fonte de recursos o Sistema Brasileiro de Poupança e Empréstimo (SBPE) e a partir de 1967, o Fundo de Garantia por Tempo de Serviço (FGTS) (BONDUKI, 2008).

3 - O Ministério das Cidades foi extinto em janeiro de 2019 e juntamente com o Ministério da Integração Nacional, se transformaram em Ministério do Desenvolvimento Regional (BRASIL, 2019).

4 - Até o ano de 1997, Campo Magro fazia parte do município de Almirante Tamandaré.

5 - Conselho Nacional do Meio Ambiente (CONAMA), criado no ano de 1982, através da Lei n $6.938 / 81$ para estabelecer a Política Nacional do Meio Ambiente.

6 - Essa informação foi levantada pelo Jornal Gazeta do Povo no ano de 2010 e publicada em reportagens nos dias 20/03/2010 e 13/10/2010.

\section{Referências Bibliográficas}

ACSELRAD, H. Ambientalização das lutas sociais - o caso do movimento por justiça ambiental. Estudos Avançados, N. 24 (68), p.103-119, 2010.

BONDUKI, N. Política habitacional e inclusão social no Brasil: revisão histórica e novas perspectivas no governo Lula. Revista eletrônica de Arquitetura e Urbanismo, São Paulo, n. 1, p. 71-104, 2008.

BRASIL. Ministério das Cidades (2010). Urbanização de Favelas: a experiência do PAC. Brasília. Disponível em:

http://www.capacidades.gov.br/biblioteca/./id/.../Urbanizacao+de+favelas. Acesso em: 28 mai. 2018.

Secretaria Nacional de Habitação. Brasília, 2017a.

BRASIL. Ministério do Planejamento. Primeiro Balanço 2015 - Paraná. Brasília, 2017b. Disponível em: http://www.pac.gov.br/sobre-o-pac/publicacoesregionais. Acesso em: 12 jan. 2018.

CAMPANHONI, A. Implementação da política federal de habitação para assentamentos precários: gestão municipal e os entraves na execução das intervenções. Revista do Serviço Público, Brasília, v. 67, n. 2, p. 227-248, 2016.

CARDOSO, A. L. Avanços e desafios na experiência brasileira de urbanização de favelas. Cadernos Metrópoles, São Paulo, p. 219-240, 2007.

CARDOSO, A. L.; ARAGÃO, T. A.; ARAUJO, F. S. Habitação de Interesse Social: Política ou Mercado? Reflexos sobre a construção do espaço metropolitano. In: XIV ENCONTRO NACIONAL DA ANPUR. Anais. Rio de Janeiro, 2011.

CARDOSO, A. L.; ARAGÃO, T. A.; JAENISCH, S. T. Vinte e dois anos de política habitacional no Brasil: da euforia à crise. Rio de Janeiro, Letra Capital: Observatório das Metrópoles, 2017. 
COLOMBO. Plano Local de Habitação de Interesse Social. Diagnóstico Habitacional. Colombo, 2012.

Prefeitura Municipal. Colombo, 2016.

COMPANHIA DE HABITAÇÃO POPULAR DE CURITIBA (COHAB-CT). Site Oficial, 2017. Disponível em: http://www.cohabct.com.br/. Acesso em: 20 ago. 2017.

COMPANHIA DE HABITAÇÃO DO PARANÁ (COHAPAR). Programa Direito de Morar - Guarituba. Curitiba, 2007.

Colombo, 2012.

Projeto de Trabalho Técnico Social. PAC/PPI - Intervenção em favelas.

Curitiba,

Plano de Recuperação Ambiental e Urbanização de Campo Magro. 2018.

Site oficial. Disponível em: http://www.cohapar.pr.gov.br. Acesso em: 08 out.

COORDENAÇÃO DA REGIÃO METROPOLITANA DE CURITIBA (COMEC). Plano de desenvolvimento integrado - PDI. Curitiba, 2006.

Revista da Região Metropolitana de Curitiba. Curitiba, 2012.

CORREA, Roberto Lobato. O espaço urbano. São Paulo: Ática, 1989.

FERREIRA, J. S. W. Produzir casas ou construir cidades? Desafios para um novo Brasil urbano. Parâmetros de qualidade para a implementação de projetos habitacionais e urbanos. São Paulo: FUPAM, 2012.

FIRKOWSKI, O. L. C. de F. A nova territorialidade da indústria e o Aglomerado Metropolitano de Curitiba. 2001. 225 f. Tese (Doutorado em Geografia), Faculdade de Filosofia, Letras e Ciências Humanas, Universidade de São Paulo.

GAZETA DO POVO. Site oficial. Disponível em: http://wwwwgazetadopovo.com.br. Acesso em: jun. 2017.

INSTITUTO BRASILEIRO DE GEOGRAFIA E ESTATISTICA (IBGE). Censo 2010: Aglomerados Subnormais - Informações Territoriais. Disponível em: http://www.ibge. gov. br/home/presidencia/noticias/imprensa/ppts. Acesso em: mai. 2018.

INSTITUTO PÓLIS. Regularização fundiária e moradia: o que é e como implementar. São Paulo: Instituto Pólis - Caixa Econômica Federal, 2002.

LIMA, C. A. A ocupação de área de mananciais na Região Metropolitana de Curitiba: do planejamento à gestão ambiental urbana-metropolitana. 2000. 345 f. Tese (Doutorado em Meio Ambiente). Programa de Doutorado em Meio Ambiente e Desenvolvimento, Universidade Federal do Paraná.

Considerações sobre ocupações irregulares e parcelamento urbano em áreas de mananciais da Região Metropolitana de Curitiba/PR. Revista de Desenvolvimento e Meio Ambiente, UFPR, n. 3, p. 97-117, 2001.

LIMA, C. A.; CAMPOS, M. L. B. TERBECK, M. I. Ocupação urbana em área de mananciais: análise de densidade e índice de ocupação como evidencias de um padrão em consolidação nos municípios de Piraquara e Pinhais - Região Metropolitana de Curitiba. In: MOURA, R; FIRKOWSKI, O. L. C. de F. Dinâmicas intrametropolitanas 
e produção na RMC. Letra Capital: Observatório das Metrópoles, Curitiba, 2009. p. 269-294.

LOJKINE, J. O Estado capitalista e a questão urbana. $2^{\circ}$ ed. São Paulo, Martins Fontes, 1997.

MARICATO, Ermínia. Urbanismo na periferia do mundo globalizado: metrópoles brasileiras. São Paulo em Perspectiva, v. 14 (4). São Paulo, p. 21-33, 2000.

MARQUES, E. C. Notas críticas à literatura sobre o Estado, Políticas Estatais e Atores Políticos. BIB, n. 43, Rio de Janeiro, p. 67-102, 1997.

MARTINS, M. L. R. São Paulo, centro e periferia: a retórica ambiental e os limites da política urbana. Estudos Avançados, n. 25, v. 71. São Paulo, p. 59-71, 2011.

MILLIBAND, R. O Estado na sociedade capitalista. Rio de Janeiro, Zahr, 1972.

MOURA, R.; RODRIGUES, A. L. (Org.) Como andam Curitiba e Maringá. Rio de Janeiro: Letra Capital, Observatório das Metrópoles, 2009.

PIRAQUARA. Plano Diretor Municipal. Piraquara, 2006.

Plano Municipal de Regularização Fundiária Sustentável. Relatório do Trabalho Social. Piraquara, 2013.

Prefeitura Municipal. Piraquara, 2016.

RITTER, C. Os processos de Periferização, Desperiferização e Reperiferização e as transformações socioespaciais no Aglomerado Metropolitano de Curitiba. 2011. 298 f. Tese (Doutorado em Geografia) - Setor de Ciências da Terra, Universidade Federal do Paraná.

RUFINO, M. B. Incorporação da Metrópole: centralização do capital no imobiliário e a nova produção do espaço em Fortaleza. 2012. 264 f. Tese (Doutorado em de Arquitetura e Urbanismo). Faculdade de Arquitetura e Urbanismo da Universidade de São Paulo.

SANTOS, M. A urbanização brasileira. 3 ed. São Paulo: HUCITEC, 1996.

SILVA, M. N. A dinâmica de produção dos espaços informais de moradia e o processo de metropolização em Curitiba. 2012. 260 f. Tese (Doutorado em Geografia). Setor de Ciências da Terra, Universidade Federal do Paraná.

SOUZA, M. L. Proteção ambiental para quem? A instrumentalização da ecologia contra o direito à moradia. Mercator, Fortaleza, v. 14, n. 4, Número Especial, p. 25-44, 2015. 